Marquette University

e-Publications@Marquette

Economics Faculty Research and Publications

Economics, Department of

9-1-2016

Shock, but no Shift: Hospitals' Responses to Changes in Patient Insurance Mix

Kathryn L. Wagner

Marquette University, kathryn.l.wagner@marquette.edu

Accepted version. Journal of Health Economics, Vol. 49 (September 2016): 46-58. DOI. (C) 2016 Elsevier. Used with permission. 


\title{
Shock, but no Shift: Hospitals' Responses to Changes in Patient Insurance Mix*
}

\author{
Kathryn L. Wagner \\ Department of Economics, Marquette University \\ Milwaukee, WI
}

\begin{abstract}
:
Medicaid reimburses healthcare providers for services at a lower rate than any other type of insurance coverage. To account for the burden of treating Medicaid patients, providers claim that they must cost-shift by raising the rates of individuals covered by private insurance. Previous investigations of cost-shifting has produced mixed results. In this paper, I exploit a disabled Medicaid expansion where crowd-out was complete to investigate costshifting. I find that hospitals reduce the charge rates of the privately insured. Given that Medicaid is expanding in several states under the Affordable Care Act, these results may alleviate cost-shifting concerns of the reform.
\end{abstract}

Keywords: Medicaid, Health Insurance, Hospitals, Cost Shifting

JEL: I11, I13

\section{Introduction}

Health care providers receive lower reimbursements from Medicaid than any other type of health insurance. In 2012, the average Medicaid reimbursement rate was only 66 percent of the Medicare rate which is typically lower than the rate from commercial insurance plans (Zuckerman and Goin 2012). The Medicaid rate must

\footnotetext{
* I am grateful to William Evans, Daniel Hungerman, Ethan Lieber, and numerous seminar participants at the University of Notre Dame.
}

Journal of Health Economics, Vol. 49 (September 2016): pg. 46-58. DOI. This article is (C) Elsevier and permission has been granted for this version to appear in e-Publications@Marquette. Elsevier does not grant permission for this article to be further copied/distributed or hosted elsewhere without the express permission from Elsevier. 
be accepted as payment-in-full which means that providers receive no additional coinsurance payments nor can they extract any additional fees from a Medicaid patient even if the reimbursement rate is less than the total cost of care. As a result, health services providers receive less compensation from a Medicaid patient relative to a patient with any other form of health coverage and often argue that rates are not even enough to cover costs. In order to subsidize the low rates from Medicaid patients, some suggest that hospitals raise prices for privately insured patients to subsidize Medicaid patients. Don George, the President and CEO of Blue Cross Blue Shield of Vermont wrote that

"When government reimbursements are insufficient to cover the cost of the services a facility provides to Medicare or Medicaid beneficiaries, hospitals charge patients with private insurance enough to cover not only the cost of their services, but the shortfall created by government reimbursements as well" (George 2014).

Charging higher private rates to make-up for public shortfalls is referred to as cost shifting and has been believed by health care administrators to be a key strategy for managing low public reimbursement rates. ${ }^{1} \mathrm{~A}$ study by the Milliman Institute estimated that the cost-shift from public to private patients was a total of $\$ 88.8$ billion or 15 percent of all medical costs in 2006/2007 (Fox and Pickering 2008). In this article I focus on dynamic cost-shifting - a phenomenon in which a negative exogenous shock to revenue causes an increase in prices for privately insured patients.

Economists have proposed several theoretical models of hospital pricing behavior, but they produce conflicting predictions regarding the practice of dynamic cost shifting. A key takeaway from these models is that cost shifting depends on whether a hospital acts as a profit maximizer or as a utility maximizer and there is no consensus on

\footnotetext{
${ }^{1}$ Dennis Vonderfecht, CEO of Mountain States Health Alliance stated that "Existing government health care programs such as Medicaid fall short of covering actual health care costs -- meaning the company depends on 'cost-shifting' to private insurance patients, who pick up more than the cost of treatment." (McCown 2009).
}

Journal of Health Economics, Vol. 49 (September 2016): pg. 46-58. DOI. This article is ( Elsevier and permission has been granted for this version to appear in e-Publications@Marquette. Elsevier does not grant permission for this article to be further copied/distributed or hosted elsewhere without the express permission from Elsevier. 
which behavior is most common to the hospital. ${ }^{2}$ Given the inconclusive nature of the theoretical predictions, it is not surprising that the large empirical literature that has sought to estimate the existence and extent of cost shifting has produced a broad range of estimates. ${ }^{3}$

The goal of this paper is to test the cost-shifting hypothesis by exploiting recent Medicaid expansions for individuals with disabilities that reduced the average revenue per patient received by hospitals. Wagner (2015) demonstrated that these Medicaid expansions led to 100 percent crowd-out of private health coverage among the disabled population. Crowd-out occurs when newly eligible individuals with private health insurance drop their current health plans in favor of public coverage through Medicaid. Since crowd-out in the disabled Medicaid expansions was complete, the take-up of Medicaid by newly eligible individuals was offset by an equal reduction in private insurance coverage. This movement of patients from private (generous reimbursement) to Medicaid (less generous reimbursement) insurance generates lower revenues per admission and is simply a drop in revenue for health care providers. Using this change in revenue, this paper tests for the presence of cost-shifting among a population of disabled patients.

This paper is unique along a number of dimensions. First, the majority of work on hospital cost shifting has used changes to the Medicare program as a source of a shock to provider revenues. Medicaid, however, is a state run program and is inherently different from the federally run Medicare program. There are often additional expenses associated with Medicaid (lower reimbursement rates for certain procedures, difficult administrative practices, and different beneficiaries) that lead to Medicaid patients being less profitable to physicians than Medicare. Due to this difference in profitability, health care providers may have greater incentive to cost-shift in response to

\footnotetext{
2 For example, see Sloan et al. (1973), Dranove (1988), Morrisey (1996), Showalter (1997), Clement (1997), Zwanziger et al. (2000), Rosenman et al. (2000), and Friesner and Rosenman (2002).

${ }^{3}$ See Clement (1997), Gowrisankaran and Town (1997), Cutler (1998), Dranove and White (1998), Zwanziger et al. (2000), Friesner and Rosenman (2002), Dobson et al. (2006), Zwanziger and Bamezai (2006), Wu (2010), Stensland et al. (2010), and Frakt (2011) for empirical estimates of cost-shifting.
}

Journal of Health Economics, Vol. 49 (September 2016): pg. 46-58. DOI. This article is (C) Elsevier and permission has been granted for this version to appear in e-Publications@Marquette. Elsevier does not grant permission for this article to be further copied/distributed or hosted elsewhere without the express permission from Elsevier. 
changes in the Medicaid program. Additionally, the cost-shifting discussion has gained steam throughout the implementation of the policies stipulated under the Patient Protection and Affordable Care Act (PPACA). Given that one of the largest pieces of the PPACA is the expansion of the Medicaid programs in several states, examining hospital responses to an increase in Medicaid beneficiaries is especially relevant.

Second, most empirical approaches to identify cost shifting behavior have relied on changes in the actual public reimbursement rate as the source of shock to provider revenue but there are concerns that public reimbursement rates may be strategically chosen by the government in response to private prices (Glazer and McGuire 2002). Public and private patients share, to a certain degree, the privileges and procedures offered by the hospital even though private patients pay more for these services. If government payers are aware that hospitals will offer these shared services so long as private patients will pay for them, they may adjust their rates to optimize the benefit from the "commonality" of care public patients have with private patients. Thus, empirical cost shifting estimates using changes in public reimbursement rates for identification may be biased by reverse causality. The shock to revenues used in this project more closely resembles the thought experiment considered in theoretical work than previous empirical tests of the cost-shifting hypothesis since identification is from an average change in revenue per patient resulting from crowd-out in disabled Medicaid expansions. This exogenous event likely bypasses concerns of reverse causality that are present when using changes in Medicare list charges as I discuss further below.

The first step in this project is to verify the existence of the onefor-one shift in insurance types within the dataset. Wagner (2015) used data from the Survey of Income and Program Participation (SIPP) and the March Current Population Survey (CPS) to demonstrate that Medicaid expansions for the disabled generate 100 percent crowd-out. In this paper, I use data from the Nationwide Inpatient Sample (NIS) of the Healthcare Cost and Utilization Project (HCUP) from the Agency for Healthcare Research and Quality and replicate the basic results of Wagner (2015) with hospitalizations. Using Currie and Gruber's (1996a and 1996b) measure for simulated eligibility, I find that

Journal of Health Economics, Vol. 49 (September 2016): pg. 46-58. DOI. This article is ( Elsevier and permission has been granted for this version to appear in e-Publications@Marquette. Elsevier does not grant permission for this article to be further copied/distributed or hosted elsewhere without the express permission from Elsevier. 
Medicaid coverage for inpatient stays increased by roughly the same amount in magnitude as private coverage decreased. Taken together, these results imply that crowd-out within the inpatient setting is complete and there is a one-for-one relationship between Medicaid take-up and private coverage reduction for the disabled population.

I find that in response to the shift in insurance types, hospitals reduced the average charge rate for disabled patients with private insurance, while charge rates for disabled patients with other payer types are not statistically significantly different as a result of the insurance shift from the Medicaid expansion. This behavior is consistent with a Mixed Economy Model where the hospital acts as a profit maximizer (Sloan et al. 1978). These results are important given that cost-shifting has been a major concern of the Patient Protection and Affordable Care Act (PPACA). There has been much speculation that the PPACA Medicaid expansions ongoing in several states will result in increases of private out-of-pocket medical expenses and insurance premiums due to cost-shifting. The results of this paper suggest otherwise for the disabled population and that instead hospitals actually reduced charges for privately insured disabled patients. Though the PPACA Medicaid expansions affect a general population of working age adults, the results for the disabled population in this paper suggest that cost-shifting may not be the only response of a hospital when faced with a revenue reduction.

The rest of paper proceeds as follows. Section II describes our current state of knowledge of cost-shifting. Section III outlines the research strategy. Section IV details the data and estimating equations used for the study. Section $V$ presents the results of the paper. Section VI concludes.

\section{Conflicting Models and Inconclusiveness: The Ongoing Cost-Shifting Debate}

Cost-shifting occurs when one consumer type is charged a higher price so that another type can pay a lesser price relative to costs. Though this sounds very similar to price discrimination, the presence of price discrimination does not automatically imply the presence of cost-shifting. Both price discriminators and cost shifters require that the supplying firm has some market power, but under price discrimination, there does not need to be a direct connection

Journal of Health Economics, Vol. 49 (September 2016): pg. 46-58. DOI. This article is ( Elsevier and permission has been granted for this version to appear in e-Publications@Marquette. Elsevier does not grant permission for this article to be further copied/distributed or hosted elsewhere without the express permission from Elsevier. 
between the different prices the discriminator charges the different groups. In contrast, with cost-shifting there is a causal and dynamic connection between the different prices charged by cost shifters. Thus, while cost shifting always involves some degree of price discrimination, it is not always the case that price discrimination means cost shifting.

Figure I plots the times series trends of the aggregate hospital payment-to-cost ratios for private, Medicare, and Medicaid insurance in the United States from 1992 to 2012. ${ }^{4}$ The trends documented in

Figure I demonstrate a negative correlation between private and public hospital payments. This negative correlation is consistent with what cost-shifting behavior would suggest but is by no means conclusive proof of cost-shifting. Cost-shifting relies on there being a causal relationship between public and private prices and the trends in Figure I can only demonstrate a correlation. There are numerous reasons beyond cost-shifting that could potentially explain the trends in Figure I.

Previous work investigating cost-shifting has produced conflicting theoretical and empirical results. Theoretical models follow the mixed economy approach originally discussed in Sloan et al. (1978). In the mixed economy model, hospitals offer services in both a private market, where they have market power and face downward sloping demand, and a public market, where a third party (the government) sets the price. Theoretical cost-shifting models differ on one key assumption: are hospitals profit maximizers or utility maximizers? This assumption leads to different outcomes regarding the ability of firms to cost shift.

In standard market models, profit maximizing firms should have already exhausted their market power and chosen profit maximizing prices. This eliminates the possibility to further price discriminate and subsequently the ability to cost shift onto private payers (Morrisey 1996). Given that only 18 percent of US hospitals in 2011 were investor-owned (for-profit), many theorists assume hospitals to behave as utility maximizers and maximize utility from total volume of medical services in addition to profits generated (American Hospital

\footnotetext{
${ }^{4}$ The hospital payment-to-cost ratios are from the American Hospital Association's Trendwatch Chartbook.
}

Journal of Health Economics, Vol. 49 (September 2016): pg. 46-58. DOI. This article is ( Elsevier and permission has been granted for this version to appear in e-Publications@Marquette. Elsevier does not grant permission for this article to be further copied/distributed or hosted elsewhere without the express permission from Elsevier. 
Association 2013). While utility maximizing behavior does not guarantee the use of cost-shifting, it does allow for the possibility unlike profit maximization.

Given the conflicting predictions of profit and utility maximizing approaches, several studies have attempted to empirically test for the presence of cost-shifting behavior. These studies focus not only on whether hospitals cost shift, but also to what extent cost shifting occurs. Empirical estimates of cost-shifting are widely mixed though most find small extents of cost-shifting if they find that it does occur. ${ }^{5}$ The goal of this paper is to add to the empirical literature on cost shifting by using a new approach in which I test for the presence of cost-shifting as a response to a shift in patient insurance mix from a Medicaid expansion.

One concern with current cost shifting estimates is that it is measured in terms of direct changes to the actual public reimbursement rate (usually Medicare) and it is possible that these rates are not chosen exogenously. Once admitted to a hospital, patients share to a certain degree in services and amenities the hospital offers no matter their insurance type. For example, most hospitals will not have two separate MRI machines, one a top-of-theline model for higher paying private patients and the other an old outof-date model for the government reimbursed public patients. The hospital cafeteria will also not have two separate menus where private patients are offered steak and lobster and the public patients are offered bologna sandwiches. Thus, when a hospital makes an investment into new equipment or amenities, it is likely that both types of patients will benefit to some degree and we refer to this phenomenon as the "commonality" of care amongst patients.

If the degree of commonality is substantial between the two types, then public patients benefit from the level of care for which private patients pay higher prices. Payment rates set by hospitals for the private market reflect not only the cost of the actual treatment for a patient, but also investments into new equipment or training,

\footnotetext{
${ }^{5}$ Several empirical studies attempt to measure the extent of hospital cost shifting empirically. Studies include Clement (1997), Gowrisankaran and Town (1997), Cutler (1998), Dranove and White (1998), Zwanziger et al. (2000), Friesner and Rosenman (2002), Dobson et al. (2006), Zwanziger and Bamezai (2006), Wu (2010), and Stensland et al. (2010). These are effectively summarized in Frakt (2011), Table 2.
}

Journal of Health Economics, Vol. 49 (September 2016): pg. 46-58. DOI. This article is ( Elsevier and permission has been granted for this version to appear in e-Publications@Marquette. Elsevier does not grant permission for this article to be further copied/distributed or hosted elsewhere without the express permission from Elsevier. 
maintenance and upkeep of facilities, and general amenities the hospital chooses to offer. The government is aware of the fact that public patients benefit from these investments even though the hospital is not reimbursed at the same rate for providing them treatment. It is possible that the government can strategically set the public reimbursement rate (with knowledge of the private rate) with the intent of optimizing the degree of commonality between public and private patients (Glazer and McGuire 2002). Thus, the private rates could actually influence the government rate setting process which would result in reverse causality in the empirical equation. It is therefore a concern that empirical estimates may be biased when a direct change in public reimbursement rates is used for identification. In this paper, my research strategy will not use a change in the reimbursement rate for identification and the empirical estimates will avoid any reverse causality concerns originating from strategic public price setting.

Another limitation of current cost shifting estimates is that most of them are estimated relative to changes in the Medicare program. The Medicaid program, even though it is slightly smaller than the Medicare program, is another important public health insurance program in the United States. In 2012, Medicaid expenditures were $\$ 421.2$ billion which is 25 percent less than total Medicare spending (\$572.5 billion) (Centers for Medicare and Medicaid Services, 2014). Though both programs provide health insurance to their recipients using government funds, Medicaid and Medicare are incredibly different programs.

First, the two programs have different funding and administrative practices. Medicare is entirely federally funded with all of its eligibility requirements, reimbursement rates, and operating procedures completely determined by the federal government. Medicaid, on the other hand is a state-run program that is duallyfunded by both the state and federal governments. States are allowed to choose their own eligibility requirements, reimbursement rates/policies, and coverage options and as long as these selections meet federal minimums, the federal government will reimburse at least 50 percent of all Medicaid expenditures. ${ }^{6}$ Given that states are

\footnotetext{
${ }^{6}$ The federal reimbursement rate of Medicaid expenses in each state is called the Federal Medical Assistance Percentage (FMAP). States receive an FMAP of at least 50 percent but no
}

Journal of Health Economics, Vol. 49 (September 2016): pg. 46-58. DOI. This article is ( Elsevier and permission has been granted for this version to appear in e-Publications@Marquette. Elsevier does not grant permission for this article to be further copied/distributed or hosted elsewhere without the express permission from Elsevier. 
the administrators of their own programs, Medicaid program characteristics can vary quite a bit across states whereas Medicare is virtually the same throughout the entire country. These differences in administration could result in longer reimbursement periods and increased processing time for patients leading to additional costs for the provider (both in time and money). Additionally, Medicaid reimbursement rates are not the same as Medicare's and can be considerably lower for certain procedures. These added costs in conjunction with the potential for lower payments could lead to providers having an increased incentive to cost shift for Medicaid patients.

Second, the beneficiaries covered by Medicare and Medicaid are not the same. Medicare covers mostly elderly individuals (65 or older) and those who are receiving Social Security Disability Insurance. Medicaid covers a wide variety of populations (women, children, elderly, and disabled) with the foremost eligibility requirement being that a recipient must have low income and limited financial resources. The Medicare program has no income restriction to qualify and most of its beneficiaries are actually required to pay some type of coinsurance fees. ${ }^{7}$ The bulk of Medicaid policies require no type of copayment for treatment. Given the diversity in their beneficiaries, it is possible that hospitals and health care providers may respond differently to changes in the two programs and so it is important to investigate cost shifting from a Medicaid perspective which is what is pursued in this paper. See Appendix A.2 for a more detailed description of previous costshifting literature.

\section{Research Strategy}

To improve upon earlier work, I employ an alternative method of identifying cost shifting that avoids using a change in the reimbursement rate and also measures cost-shifting from a Medicaid perspective. I take advantage of a unique Medicaid expansion described in Wagner (2015). The Omnibus Reconciliation Act of 1986 (OBRA86) gave states the authority to increase Medicaid income

more than 74.73 percent. States with lower incomes per capita relative to the US income per capita receive higher reimbursement rates from the federal government (Baumrucker 2010).

${ }^{7}$ Coinsurance fees for individuals who are dually eligible for both the Medicaid and Medicare programs are paid for by their Medicaid program.

Journal of Health Economics, Vol. 49 (September 2016): pg. 46-58. DOI. This article is ( Elsevier and permission has been granted for this version to appear in e-Publications@Marquette. Elsevier does not grant permission for this article to be further copied/distributed or hosted elsewhere without the express permission from Elsevier. 
eligibility for disabled individuals up to 100 percent of the Federal Poverty Level (FPL). Prior to this authorization, the majority of disabled individuals had to qualify for Medicaid through the Supplemental Security Income Program (SSI) which had an eligibility cutoff of approximately 74 percent of the FPL. By 2003, 21 states and the District of Columbia had enacted the OBRA86 expansion (Herz et al. 2006).

A major concern with any public health insurance program expansion is the potential for crowd-out - when individuals with private insurance gain Medicaid eligibility and drop their private coverage in favor of public benefits. The rate of crowd-out has been a key focus of the public health insurance expansion literature and crowd-out for children and families has been estimated to be as high as 50 percent though results have been mixed across studies and methodologies. ${ }^{8}$ Wagner (2015) investigated the degree of crowd-out in the disabled Medicaid expansions authorized under the OBRA86. Using both the March Current Population Survey and the Survey of Income and Program Participation, the study finds that crowd-out for the disabled population was large. The 2SLS estimates imply that for every individual who took up Medicaid through the eligibility expansions someone lost their private insurance. ${ }^{9}$

Since crowd-out in these expansions was complete, disabled individuals shifted from private health insurance (generous reimbursement) to Medicaid coverage (less generous reimbursement) with little change to the overall insurance rate. Given this shift, the overall patient pool had less revenue generating capability after the expansions, reducing revenue to hospitals without any direct change to

\footnotetext{
${ }^{8}$ See Aizer and Grogger (2003), Blumberg et al. (2000), Card and Shore-Sheppard (2004), Cutler and Gruber (1996), Dubay and Kenney (1996) and (1997), Gruber and Simon (2008), Ham and Shore-Sheppard (2005), Hamersma and Kim (2013), Hudson et al. (2005), LoSasso and Buchmueller (2004), Shore-Sheppard (2008), Thorpe and Florence (1998), and Yazici and Kaestner (2000). See Hamersma and Kim (2013) and Gruber and Simon (2008) for a review of this literature.

${ }^{9}$ These results are thought to indicate a switch from private to public coverage by the individuals who take-up Medicaid coverage. Since the analysis uses cross sectional data from the March CPS and the SIPP (even though the SIPP is a panel data set it is treated as cross sectional for the analysis) this cannot be stated conclusively given that the cross sectional data surveys different individuals over time. The results do indicate a compositional change of insurance coverage type for individuals who become eligible for Medicaid coverage through the expansion.
}

Journal of Health Economics, Vol. 49 (September 2016): pg. 46-58. DOI. This article is (C) Elsevier and permission has been granted for this version to appear in e-Publications@Marquette. Elsevier does not grant permission for this article to be further copied/distributed or hosted elsewhere without the express permission from Elsevier. 
the Medicaid reimbursement rate itself. Thus, the degree of crowd-out resulting from changes to Medicaid eligibility can be used to identify any changes in hospital pricing behavior resulting from the reduction to revenue. A benefit to this strategy is that we avoid the potential for reverse causality that originates from strategic pricing to optimize patient commonality of care.

Figure II presents a graphical representation of predictions of the effect of crowd-out on medical prices from the mixed economy model. In the price setting market (private health insurance), health care providers face a downward sloping demand curve Demand 1 that corresponds to marginal revenue curve $\mathrm{MRP}_{1}$ and have a marginal cost curve MC. Since the government has complete control over the prices paid to providers for treating public patients, the government reimbursed market is represented by the horizontal line at a fixed reimbursement rate, $\mathrm{P}_{\mathrm{m}}$. Prior to the public insurance expansion, health care providers face the marginal revenue curve ACD and will offer $Q$ amount of medical services at a price of $P_{1}$ if they have $a$ marginal cost curve given by MC.

When Medicaid eligibility is expanded and crowd-out occurs, patients will shift from insurance carriers in the private market to Medicaid coverage in the government reimbursed market. Since the expansions only affect the eligibility standards, the public reimbursement rate, $\mathrm{P}_{\mathrm{m}}$, is not altered and the government market demand curve is unaffected by the legislation. In the private market, the shift in insurance type means that $M R P_{1}$ will rotate to $M R P_{2}$ (Demand 1 rotates to Demand 2) since the number of privately covered patients is reduced (Garthwaite 2012). A key advantage of the Medicaid expansions for individuals with disabilities is that crowdout was essentially complete. This means that there will be no countervailing effects on hospital revenue resulting from the uninsured gaining access to health coverage through Medicaid. ${ }^{10}$ After the expansion, the hospital now faces a marginal revenue curve $A B C D$ and the price for the provider with supply curve $M C$ will decrease from $P_{1}$ to

\footnotetext{
${ }^{10}$ If the uninsurance rate were to decrease, then this would suggest that some previously uninsured individuals gained insurance coverage. This could result in a positive shock to provider revenue, since prior to the expansion hospitals received zero reimbursement from these patients and are now receiving at least the Medicaid level of reimbursement. Since the uninsurance rate remains unchanged, there is no counterveiling effect on provider revenue and only a revenue reduction.
}

Journal of Health Economics, Vol. 49 (September 2016): pg. 46-58. DOI. This article is ( Elsevier and permission has been granted for this version to appear in e-Publications@Marquette. Elsevier does not grant permission for this article to be further copied/distributed or hosted elsewhere without the express permission from Elsevier. 
$P_{2}$. The new level of medical services provided decreases from the original $Q$, but will be higher than if the price had remained at $P_{1}$ accounting for the new Demand. Note also, that according to the model, only providers who treat at least some patients in the private market will be impacted. Those who are operating solely in the Medicaid market will not experience a shift in the demand curve. Thus, the model predicts that the opposite of cost shifting will occur. That is, hospitals will actually lower their prices for privately covered patients.

There may be a concern that state governments can control the level of crowd-out in a public insurance expansion in such a way as to optimize the commonality of care between public and private patients. If governments have this ability, then cost-shifting estimates using my research strategy are potentially subject to the same biases as those that are measured relative to the public reimbursement rate as was the case in earlier literature. There are several reasons why this is not an issue. Unlike the Medicaid reimbursement rate, states cannot directly set the level of crowd-out in a public insurance expansion. They can only control the eligibility levels which indirectly influence the degree of crowd-out. It is hard to imagine that states have great control over the degree of crowd-out purely through eligibility levels. Even further, the OBRA86 expansions only allowed states to select eligibility levels below 100 percent of the FPL so they did not have free reign over their eligibility standards.

Another reason I suspect that the strategic selection of crowdout is not an issue in this case is the large magnitude of the crowd-out rate. Crowd-out is a contentious issue in public health insurance expansions drawing much debate and criticism. As a result, governments would ideally desire for the level of crowd-out to be as close to zero as possible and we would expect any type of state selection to bias the rate of crowd-out down. Given that the rate of crowd-out for the Medicaid disability expansion was 100 percent (essentially the highest possible level), this suggests that states were not strategically capable of selecting the degree of crowd-out within these expansions.

Journal of Health Economics, Vol. 49 (September 2016): pg. 46-58. DOI. This article is ( Elsevier and permission has been granted for this version to appear in e-Publications@Marquette. Elsevier does not grant permission for this article to be further copied/distributed or hosted elsewhere without the express permission from Elsevier. 


\section{Data and Estimating Equations}

\section{A. Data}

The main data source for this project is the Nationwide Inpatient Sample (NIS) which is part of the Healthcare Cost and Utilization Project (HCUP) produced by the Agency for Healthcare Research and Quality. The HCUP NIS contains information on discharges from nearly 8 million hospital stays each year in the United States that includes patient demographics, hospital identifiers, duration of hospital stay, diagnosis codes, total charges, and expected payment source (i.e. insurance type). Weighted, the HCUP NIS represents nearly 35 million hospital stays each year (HCUP databases 2009). Though the HCUP NIS contains a varying number of participating states over time, with proper weighting the sample of discharges in the dataset should be stratified in such a way to be a national representation of all inpatient discharges in the United States. My analysis will use data from the 1995-2007 HCUP NIS. ${ }^{11}$

I impose a number of restrictions to construct my study sample. The Medicaid expansions being examined in this paper only apply to individuals with disabilities. Thus, the main sample only considers discharges where the patient had a disability. For the purposes of this paper, I define disability to be the presence of a chronic condition on a patient's discharge record since chronic disease is the leading cause of disability. I describe in a later section how I determine within the NIS if a patient has a chronic condition. Given that most individuals 65 years and over are automatically covered by Medicare, I restrict the sample to individuals under 65 years old. Children (individuals under the age of 20) are eliminated from the sample since Medicaid has higher eligibility levels for them. Women are excluded due to their potential to qualify for Medicaid coverage if they are pregnant. Many Medicaid programs also provide coverage to women who are diagnosed with breast or cervical cancer. Given these other prospective coverage pathways for women, the study sample only includes men.

A person's race is strongly related to their participation in the Medicaid program and I exclude 10 states not reporting this

\footnotetext{
${ }^{11}$ The $100 \%$ NIS sample is used for the analysis though smaller subsets of the data are available.
}

Journal of Health Economics, Vol. 49 (September 2016): pg. 46-58. DOI. This article is (C) Elsevier and permission has been granted for this version to appear in e-Publications@Marquette. Elsevier does not grant permission for this article to be further copied/distributed or hosted elsewhere without the express permission from Elsevier. 
information. One additional state (Wisconsin) was also excluded due to inconsistent charge reporting noted by HCUP in their data documentation. The final sample contains 30 of 41 possible states. To reduce the computational dimension of the problem some, only the top 100 primary diagnosis codes are used in the main analysis. These diagnosis codes account for 57 percent of all disabled male discharges and 52 percent of all disabled male medical charges in the HCUP NIS.

A limitation to the HCUP NIS is that it only contains information regarding total charges rather than total payments for each discharge. Though the terms payments and charges are often used interchangeably, they do not often refer to the same measurements. Given that these measurements are often not the same, we may be concerned about what results on charges in the HCUP NIS may imply about potential impacts on actual payments. I address this concern in Appendix A.3, by making a comparison between the charges for private insured patients from the HCUP NIS and the payments contained in the MarketScan Commercial Claims and Encounters database. The analysis suggests that charges and payments are related, but the measurement between the two is noisy (see Appendix A.3 for further detail).

A unique quality of the HCUP NIS is that it contains data for multiple insurance types: Private, Medicaid, Medicare, Self-pay, Charity-care, and Other. The insurance type of "other" contains a wide variety of insurance policies including military/veteran's insurance, workman's compensation, and state-specific insurance pools. Since the insurance policies contained in this group are so broad, I exclude individuals with "other" insurance type from the main sample. ${ }^{12}$

Summary statistics for the final sample are presented in Table I. The final sample contains almost 4.9 million male discharges. Males with private insurance account for 49 percent of the sample while Medicaid and Medicare each account for 19 and 21 percent, respectively. The remaining discharges are either covered by self-pay (uninsured) or charity-care from the hospital. The average charges per discharge were $\$ 26,279$ in real 2007 dollars with an average duration of hospital stay equal to 5.2 days. The sample was

${ }^{12}$ Only $6 \%$ of disabled working age male discharges in the HCUP NIS were reported as having "other" type of health insurance.

Journal of Health Economics, Vol. 49 (September 2016): pg. 46-58. DOI. This article is @ Elsevier and permission has been granted for this version to appear in e-Publications@Marquette. Elsevier does not grant permission for this article to be further copied/distributed or hosted elsewhere without the express permission from Elsevier. 
NOT THE PUBLISHED VERSION; this is the author's final, peer-reviewed manuscript. The published version may be accessed by following the link in the citation at the bottom of the page.

approximately 70 percent white, 19 percent black, and 9 percent Hispanic.

\section{B. Identifying Disability}

The HCUP NIS does not directly report whether a patient has a disability and since the Medicaid expansions being used for identification are only for those with disabilities, it is important to utilize an appropriate method of identifying disabled individuals within the HCUP NIS. The definition of disability used for Medicaid eligibility determination is the same as the definition used by the Social Security Administration (SSA) for SSI qualification. SSA guidelines dictate that an adult is considered disabled if she has a "medically determinable physical or mental impairment" that prevents "substantial gainful activity" and is expected to "result in death" or has "lasted or can be expected to last for a continuous period of not less than 12 months" (Social Security Administration 2012). This definition is very broad and relies heavily on a physician's judgment.

In this paper, I will use the presence of a chronic condition as a proxy for disability. Though they are not perfectly correlated with the SSA's disability definition, chronic conditions are the leading cause of disability in the United States and are likely strongly related (CDC, 2014). The most common causes of disability over the study period were all prominent chronic conditions (Hootman et al. 2005). Using the diagnosis code information from each discharge contained within the NIS, I can identify whether an individual has some form of chronic disease. To do this I use the Johns Hopkins Adjusted Clinical Groups (ACG) System which will take the diagnosis codes from the discharge record, determine which of these codes are considered to be chronic conditions, and then form a count of total chronic conditions on a patient's record. I then consider a patient to be disabled if they have one or more chronic conditions reported on their diagnosis record. The top five primary diagnosis codes for men with at least one chronic condition on their record are reported in Table II. Most of these conditions are related to heart or lung problems which were the most commonly reported forms of disability in the 2005 Survey of Income and Program Participation.

Journal of Health Economics, Vol. 49 (September 2016): pg. 46-58. DOI. This article is (C) Elsevier and permission has been granted for this version to appear in e-Publications@Marquette. Elsevier does not grant permission for this article to be further copied/distributed or hosted elsewhere without the express permission from Elsevier. 
NOT THE PUBLISHED VERSION; this is the author's final, peer-reviewed manuscript. The published version may be accessed by following the link in the citation at the bottom of the page.

\section{Measuring Crowd-out}

In order to evaluate the expansion's effect on the cost shifting behavior of hospitals, we need to construct a measure of the shift in insurance type that results from crowd-out. In the public insurance expansion literature that attempts to measure crowd-out, authors use data at the individual level to construct dependent variables that are dummy variables measuring insurance status such as having Medicaid or private insurance. These insurance status variables are then regressed on a dummy variable that measures whether the respondent is eligible for the Medicaid program. Eligibility status in these studies is imputed using reported financial and family information and as such likely contains measurement error. The regression is also subject to an omitted variables bias in that there is a mechanical reverse correlation between dependent and independent variables since disabilities reduce earnings and lower earnings people are more likely to qualify for Medicaid. To correct for both of these issues, the model is estimated with 2SLS using a suitable instrument for Medicaid eligibility.

Wagner (2015) uses the simulated eligibility instrument originally outlined in Currie and Gruber (1996a and 1996b) to investigate the crowd-out rate in the Medicaid expansions for individuals with disabilities. Simulated eligibility uses a fixed national population and compares that population to a state's annual Medicaid eligibility rules. The share of the fixed sample that qualifies for Medicaid under a state's rules represents the simulated instrument. Thus states with more generous Medicaid programs will have higher simulated eligibility. Wagner (2015) uses this simulated measure to instrument for imputed eligibility and finds that for every 100 people made eligible through the expansion, nearly 41 took up Medicaid coverage while 44 lost private coverage. Taken together, these results suggest that individuals shifted onto public coverage from private coverage at an approximately one-for-one rate.

The data necessary to construct simulated eligibility is the Medicaid qualification rules for the disabled from 1995 to 2007 by state. Disabled individuals have multiple routes they can pursue in order to gain Medicaid coverage such as poverty related coverage through the OBRA86, the Supplemental Security Income Program, or the State Supplemental Payment Program. During the study period,

Journal of Health Economics, Vol. 49 (September 2016): pg. 46-58. DOI. This article is @ Elsevier and permission has been granted for this version to appear in e-Publications@Marquette. Elsevier does not grant permission for this article to be further copied/distributed or hosted elsewhere without the express permission from Elsevier. 
poverty related coverage is experiencing the most changes and most of the variation is derived from this pathway. Taking into account the eligibility rules of all these different avenues, I construct an upper income limit - the maximum amount of income an individual with a disability is allowed to possess and still qualify for Medicaid coverage under one of the programs. ${ }^{13}$ Table III contains the upper income limits for states in the sample in their first year of reporting to the HCUP NIS and the last year of the sample period (2007). These upper income limits demonstrate that there is quite a bit of variation in Medicaid eligibility rules across states and time.

Following the strategy employed in Wagner (2015), I use the March Current Population Surveys from 1996 to 2008 and restrict the sample to men between the ages of 20 and 64 who report having a work limiting disability. ${ }^{14}$ Using this sample, the simulated eligibility measure is constructed as the percentage of disabled men that would be eligible for Medicaid coverage under each state's eligibility rules by year. These percentages are then matched by state and year to the HCUP NIS. The simulated instrument is a measure of Medicaid generosity by state and year that reflects variation in the legislative changes in eligibility rules and not changes in the characteristics of a state's population. Simulated eligibility acts as a measure of how likely crowd-out is to occur and we can use simulated eligibility as a measurement of a shock to provider revenue. The simulated eligibility levels for a state in their first and last year of the sample are displayed in Table III along with the corresponding upper income limits that generated them.

The variation in the instrument is generated by changes in state legislation concerning Medicaid eligibility rather than individual

\footnotetext{
${ }^{13}$ These rules were compiled from published sources following strategies described in Brown et al. (2007) and Coe (2005). The specific sources used to construct the upper income threshold of Medicaid eligibility rules for the aged and disabled were Brown et al. (2007) , Bruen, Wiener, and Thomas (2003), Bruen, Wiener, Kim, and Miazad (1999), Coe (2005) , Congressional Research Service (1993), De Nardi et al. (2011), Horvath (1997), Kaiser Commission on Medicaid and the Uninsured (2010), Kassner (2000), Mississippi Division of Medicaid (1991-2008), Social Security Administration (1991-2008), Stone (2002, 2011), and state Medicaid websites.

${ }^{14}$ Wagner (2015)'s primary analysis relied on data from the Survey of Income and Program Participation (SIPP) which is a monthly level household survey, but found similar results using the March CPS. Given that the NIS is an annual survey, this paper uses the March CPS to construct simulated eligibility in order to better align with the timeline of the NIS.
}

Journal of Health Economics, Vol. 49 (September 2016): pg. 46-58. DOI. This article is (C) Elsevier and permission has been granted for this version to appear in e-Publications@Marquette. Elsevier does not grant permission for this article to be further copied/distributed or hosted elsewhere without the express permission from Elsevier. 
characteristics of a state and its residents. For this measure to provide consistent estimates it must be the case that the changes in the legislation are exogenous. This observation is consistent with the assumption that states experiencing increased eligibility in their Medicaid rules did not have different trends in coverage rates compared to states with static eligibility rules over the same period. Using disabled working age individuals from the March CPS 1992 to 2008, I test whether there is a difference in pre-treatment trends in insurance coverage between reform and non-reform states. ${ }^{15}$ The results indicate no significant difference between trends pre and post expansion. See the Appendix A.1 for the results of this analysis.

\section{Estimating Equations}

Given that the HCUP NIS contains millions of discharges, my analysis will collapse the HCUP NIS into cells based on hospital, time, insurance type, and various discharge characteristics. Collapsing the data in this way will help to reduce the computational strain of the regression when I control for various fixed effects and calculate clustered standard errors. In order for the identification strategy I am proposing to be valid, it must be the case that a shift in insurance types occurred in the HCUP NIS data as a result of the Medicaid expansions for the disabled. To verify that such a shift did occur, I use the collapsed data to estimate the following equation:

$$
\begin{aligned}
& \text { Insurance Type }_{h t d}=\sigma+\theta \text { simelig }_{h t}+\partial_{h}+K_{t}+\rho_{d}+ \\
& \varepsilon_{h t d}
\end{aligned}
$$

where $h, t$, and $d$ represent the hospital, time, and discharge characteristics, respectively. The dependent variable in this equation, Insurance Type $e_{h t d}$, is an indicator variable that equals 1 if the insurance type of the cell is of a certain type and 0 otherwise. Using the constructed sample of discharges from the HCUP NIS, Equation (1)

\footnotetext{
${ }^{15}$ The sample contains observations from all states and not just HCUP participating states to fully document no difference in the pre-trends for all reforming and non-reforming states.
}

Journal of Health Economics, Vol. 49 (September 2016): pg. 46-58. DOI. This article is (C) Elsevier and permission has been granted for this version to appear in e-Publications@Marquette. Elsevier does not grant permission for this article to be further copied/distributed or hosted elsewhere without the express permission from Elsevier. 
is estimated for four types of insurance coverage: Private, Medicaid, Medicare, and Uninsured/Charity.

Hospital, time, and discharge characteristic fixed effects are given by $\partial_{h}, \kappa_{t}$, and $\rho_{d}$, respectively. Hospitals are identified using the hospital identification variable provided within the HCUP NIS. Time fixed effects account for both the year and the quarter of the discharge. Discharge characteristic fixed effects control for the primary diagnosis, race, age, and duration of stay of the patient. The primary diagnosis codes follow the International Classification of Diseases version 9 Clinical Modification (ICD-9-CM). Race includes indicators for whether a patient is white, black, Hispanic, Asian/Pacific Islander, Native American, or other. Age is broken down into five categories: 20-29, 30-39, 40-49, 50-59, and 60-64 years old. Duration of hospital stay is divided into 7 groups: $0-4,5-9,10-14,15-$ $19,20-24,25-29$, and 30+ days. The key variable of interest in Equation (1), simelig $g_{h t}$, is simulated disabled Medicaid eligibility for hospital, $h$, in time, $t$, . The coefficient on this variable, $\theta$, measures the impact of the Medicaid expansions on insurance type and demonstrates the mechanism behind the change in provider revenue. Since Medicaid expansions are determined by the state, I cluster the standard errors at the state level to allow for any arbitrary correlation. ${ }^{16,17}$ Regressions are weighted by the NIS discharge weight that have been aggregated to the hospital-time-discharge characteristic-insurance cell level.

Once the insurance shift is verified within the HCUP NIS, we can then proceed to investigate the direct effect of Medicaid crowdout on the charge rates by insurance type. To do this I estimate Equation 2:

\footnotetext{
${ }^{16}$ I have also run specifications where I cluster at the hospital level and the results are similar. The structure of HCUP NIS is such that some hospitals are sampled for more than one year, but this is not the case for all years and all hospitals. Since Medicaid eligibility is set at the state level, it is likely that the appropriate correlation we need to account for is within the state.

17 I bootstrapped a few of my standard errors since I had only 30 clusters. Given that the computational demand of the bootstrapping procedure is large, I only did this for a few regressions. The statistical significance of the results did not change greatly.
}

Journal of Health Economics, Vol. 49 (September 2016): pg. 46-58. DOI. This article is ( Elsevier and permission has been granted for this version to appear in e-Publications@Marquette. Elsevier does not grant permission for this article to be further copied/distributed or hosted elsewhere without the express permission from Elsevier. 


$$
\begin{aligned}
& \ln \left(\text { Charge Rate }_{h t d}\right)=\alpha+\beta \text { simelig }_{h t}+\delta_{h}+\tau_{t}+ \\
& \gamma_{d}+\varepsilon_{h t d}
\end{aligned}
$$

The indices and simelight are defined the same as they were for Equation 1. Hospital, time, and diagnosis fixed effects are defined similarly and are given by $\delta_{h}, \tau_{t}$, and $\gamma_{d}$, respectively. The dependent variable, Charge Rate $_{h t d}$, is constructed by dividing the sum of the total charges by the total number of patients in each hospital-timedischarge characteristic-insurance cell. Equation 2 is then estimated separately for each of the four types of insurance. The key variable of interest is again, simelig $g_{h t}$, with $\beta$ as the estimate of the impact of the insurance shift on the log charge rate for hospital $h$, at time $t$, with discharge characteristics $d$.

\section{Results}

\section{A. Shifts in Patient Insurance Mix in the HCUP NIS}

A crucial step in this study is to verify the results from Wagner (2015) by showing that estimates from Equation (1) imply complete crowd-out of private health coverage by the Medicaid expansions for the disabled. Estimates of Equation (1) are presented in Table IV. The estimate of the coefficient on simulated eligibility in column 1 of Table IV suggests that for a ten percentage point increase in simulated eligibility, there was a 3.48 percentage point decrease in the number of private discharges. This estimate is statistically significant at the 1 percent level. The effect of simulated eligibility on Medicaid coverage (column 2 of Table IV) is an increase of 2.98 percentage points for a ten percentage point increase in simulated eligibility and is statistically significant at the 5 percent level. These estimates suggest a crowd-out rate equal to 117 percent and are consistent with the results found in Wagner (2015) which estimated the rate of crowd-out to be around 110 percent using data from the SIPP. ${ }^{18}$ The shifting from private

\footnotetext{
${ }^{18}$ The rate of crowd-out is constructed as the share of Medicaid take-up that is accounted for by private coverage reduction.
}

Journal of Health Economics, Vol. 49 (September 2016): pg. 46-58. DOI. This article is (C) Elsevier and permission has been granted for this version to appear in e-Publications@Marquette. Elsevier does not grant permission for this article to be further copied/distributed or hosted elsewhere without the express permission from Elsevier. 
insurance to Medicaid coverage results in an estimated $\$ 24$ million in lost charges from the study sample of working aged disabled men. ${ }^{19}$

The estimated effects on Medicare and Uninsured/Charity coverage are considerably smaller in magnitude and statistically insignificant implying that there was little change to the overall rate of insurance. The estimates in Table IV confirm the existence of a shift from private to Medicaid coverage that generates a revenue loss to hospitals holding patient mix constant.

\section{B. Effects on the Average Charge Rate}

Given the verification of the insurance shift, we can now use simulated eligibility as a proxy to estimate an effect of the revenue reduction resulting from the private to Medicaid coverage shift on the average charge rate for patients in the HCUP NIS. Estimates of Equation 2 are presented in Table $V$ for each type of insurance coverage. For privately covered patients, a 1 percentage point increase in simulated Medicaid eligibility resulted in a reduction of the average charge rate by 1.2 percent (column 1 of Table $V$ ) which is statistically significant at the 5 percent level. Using the average charges for private patients and the average change in simulated eligibility, this estimate suggests an average decrease of $\$ 1,100$ or 4 percent per private discharge.

The effect on the average charge rate for Medicaid patients (column 2 of Table V) was virtually zero, suggesting a statistically insignificant 0.08 percent reduction in the charge rate for a 1 percentage point increase in simulated eligibility. No change in the average Medicaid charge rate is expected since hospitals have no price setting power in the Medicaid market where reimbursement is determined by the state government. The estimated effects on the charge rates for the two remaining insurance types are statistically insignificant though the estimates of their coefficients are not as close to zero as the coefficient for Medicaid. These results are consistent with the predictions of the mixed economy model from Figure II and at

\footnotetext{
${ }^{19}$ On average simulated eligibility increases by 3.3 percentage points, suggesting a 1 percentage point $(9,233$ individuals in the study sample) increase in Medicaid patients in the inpatient setting. The average difference in charges between private patients and Medicaid patients is equal to $\$ 2,622$ resulting in lost charges from crowd-out in the sample equal to $9,233 * \$ 2,622=24,208,926$.
}

Journal of Health Economics, Vol. 49 (September 2016): pg. 46-58. DOI. This article is (C Elsevier and permission has been granted for this version to appear in e-Publications@Marquette. Elsevier does not grant permission for this article to be further copied/distributed or hosted elsewhere without the express permission from Elsevier. 
the very least imply that hospitals do not employ cost-shifting strategies among disabled patients in response to the disabled Medicaid expansions. Instead, hospitals reduce charges for private patients while average charges for all other insurance types do not significantly change within the disabled population.

\section{Results for Men with No Chronic Conditions}

The Medicaid expansions only increased eligibility for individuals who had a disability. Since the HCUP NIS did not contain any direct data on whether a patient was disabled or not, I defined disability to be represented by the presence of a chronic condition on a patient's diagnosis record. We may be concerned, however, that this may not be an appropriate proxy for disability. One way to examine the validity of this definition is by looking at individuals who have no chronic conditions on their record. These individuals, by my definition, are not disabled and should therefore not experience a change in insurance coverage. Table VI presents patient insurance mix results for a sample of working age men who had no chronic diseases on their discharge record. As expected, there is no statistically significant change in any type of insurance coverage for this particular group and importantly the coefficient for Medicaid coverage is near zero. Though not explored in this paper, it is possible that there is a spillover effect on the average charge rate for non-chronic men. As a response to the decline in payments from the disabled group, hospitals may have tried to alter pricing strategies for the non-disabled group as well. This will be explored in future work.

Admittedly, the coefficient on private insurance coverage for non-chronic condition men is almost statistically significant at the $10 \%$ level and this raises some concerns regarding the identification strategy. Given that more individuals in the non-chronic market are privately insured (mean is 0.63 vs. 0.49 ) the effect is considerably smaller percentage wise for non-chronic individuals compared to the effect for chronic individuals (38 to 71 percent, respectively). The results in Table VI imply that men without chronic conditions were less likely to be covered by private insurance and essentially become uninsured or covered by charity care according to the estimates. This could lead to two possible outcomes.

Journal of Health Economics, Vol. 49 (September 2016): pg. 46-58. DOI. This article is (C Elsevier and permission has been granted for this version to appear in e-Publications@Marquette. Elsevier does not grant permission for this article to be further copied/distributed or hosted elsewhere without the express permission from Elsevier. 
First, the movement of the nonchronic from private to uninsured/charity care status could result in hospitals desiring to further intensify cost-shifting onto private patients by increasing their prices. If this be the case, then my cost-shifting estimates would be understated as this behavior would work against my current estimate, biasing them towards zero. Second, if hospitals instead decided to lower private rates in response to non-chronic private movement, then my results would be overstated as the reduction in price would work with my cost-shifting estimates.

Both of these possibilities rely on the hospital actually losing revenue from the shift of non-chronic patients from private to uninsured/charity status. Despite not having insurance, uninsured patients often end up paying at least a portion of their costs out-ofpocket allowing hospitals to at least recoup some of their losses even if the patient isn't able to pay in full. Additionally, non-chronic patients also tend to have smaller average total charges than chronic patients. Thus, it is likely that the average revenue loss from a non-chronic patient will be smaller than a chronic patient. Provided they lose revenue in the non-chronic market, it must also be the case that hospitals seek to recover it from the chronic market.

The key takeaway from the estimates in Table VI is that despite the expansions in eligibility for disabled Medicaid beneficiaries, men with no chronic conditions were unable to obtain Medicaid coverage. This suggests that the presence of a chronic condition was an appropriate method of identifying individuals who had the potential to gain public coverage through Medicaid. There is a potential, however, that my estimates may be biased by the unusual trends in private insurance in the nonchronic market. Given the reasoning above, however, I anticipate this bias to be small.

\section{Average Charges Per Day Results}

The charge rate for the analysis in Table $\mathrm{V}$ is constructed as the average total charges per discharge by insurance type. Though the results in Table $\mathrm{V}$ control for duration of stay fixed effects, we may also be interested in the effect on average total charges per day spent in the hospital. Table VII presents estimates of Equation 2 where the dependent variable is the log of average charges per day spent in the hospital. Regressions in Table VII do not control for duration of stay

Journal of Health Economics, Vol. 49 (September 2016): pg. 46-58. DOI. This article is (C Elsevier and permission has been granted for this version to appear in e-Publications@Marquette. Elsevier does not grant permission for this article to be further copied/distributed or hosted elsewhere without the express permission from Elsevier. 
fixed effects since this is accounted for in the denominator of the dependent variable. The effect on the charge rate per day for private patients in Table VII, column 1 indicates a reduction of about 1 percent for a 1 percentage point increase in simulated eligibility. This represents a decrease of about 79 dollars per day and is statistically significant at the ten percent level. Given that the average hospital stay was 5.2 days long, this translates into about $\$ 1,373$ per privately insured patient which is consistent with the estimated effect from Table V. The estimated effects on the charge rates per day for the three remaining insurance types were all statistically insignificant.

\section{E. Varying the Number of Diagnoses in the Study Sample}

The main analysis restricts the sample to the top 100 primary diagnoses among working age men with at least one chronic condition. We may be concerned, however, that this restriction is too selective and that the results presented in Table IV and Table V will vary with the number of diagnoses included in the sample. Table VIII addresses these concerns. Panel A of Table VIII presents estimates of Equation 1 and Equation 2 where the sample is restricted to the top 50 primary diagnoses among men with at least one chronic condition. Panel B of Table VIII repeats the same analysis with the top 500 primary diagnoses.

The results in Panels A and B are virtually the same as in the main analysis with the top 100 diagnoses. The rate of crowd-out is 112 percent for the top 50 diagnoses and 105 percent for the top 500 diagnoses. The reduction in the average private charge rate is 1.3 percent and 1.1 percent per 1 percentage point increase in simulated eligibility for the 50 and 500 diagnoses samples respectively. Using the average change in simulated eligibility, this translates into reductions of $\$ 1,201$ and $\$ 1,033$ for private insured patients from the top 50 and 500 diagnoses, respectively. These results are consistent with estimates from the top 100 diagnoses sample and alleviates the concern that reduction in the private charge rate is limited to a specific subsample of diagnoses among disabled men.

Journal of Health Economics, Vol. 49 (September 2016): pg. 46-58. DOI. This article is (C Elsevier and permission has been granted for this version to appear in e-Publications@Marquette. Elsevier does not grant permission for this article to be further copied/distributed or hosted elsewhere without the express permission from Elsevier. 
NOT THE PUBLISHED VERSION; this is the author's final, peer-reviewed manuscript. The published version may be accessed by following the link in the citation at the bottom of the page.

\section{Conclusion}

Cost-shifting has been a major topic of discussion within the United States healthcare market ever since cost containment through reduced public reimbursements was first proposed several years ago. Previous results (both theoretical and empirical) on cost-shifting have been mixed, but hospital and healthcare executives continue to claim that it is their main method of coping with low reimbursement rates from Medicaid or Medicare. A report by Milliman in 2006 estimated that the aggregate amount of cost-shifting (the gap between total Medicaid payments and private insurance payments) from Medicaid to Commercial patients was $\$ 16.2$ billion for hospital care alone (Fox and Pickering 2008). ${ }^{20}$

The development and implementation of the Patient Protection and Affordable Care Act has reawakened the cost-shifting debate. Given the large Medicaid expansions that are already underway in some states, many private consumers and insurance companies are speculating that increases in private out-of-pocket medical expenses and insurance premiums from cost-shifting are inevitable. The Galen Institute argued that the expansion of Medicaid through the PPACA would result in a "hidden tax" on millions of privately insured patients and lead to a vicious cycle in which more and more patients would drop private coverage because of its growing premiums (Turner and Roy 2013).

The results of this paper would suggest the opposite, however. Hospitals do not employ cost-shifting strategies to the privately insured disabled in response to the Medicaid expansions for the disabled. Instead, they actually reduce charges for privately insured patients suggesting that the privately insured disabled actually benefitted from the expansions in terms of charges. Admittedly, the Medicaid expansions for the disabled were unique and the results may not generalize to the broader populations affected by the PPACA Medicaid expansions. At the very least, however, these results suggest that cost-shifting is not the hospital's only method of dealing with lower revenues as healthcare executives often claim.

\footnotetext{
${ }^{20}$ Milliman is an independent consulting specializing in actuarial products, but the cost-shifting study cited here was requested by America's Health Insurance Plans, the American Hospital Association, the Blue Cross Blue Shield Association, and Premera Blue Cross.
}

Journal of Health Economics, Vol. 49 (September 2016): pg. 46-58. DOI. This article is (C) Elsevier and permission has been granted for this version to appear in e-Publications@Marquette. Elsevier does not grant permission for this article to be further copied/distributed or hosted elsewhere without the express permission from Elsevier. 
An important aspect not explored in this paper are the mechanisms by which the cost reduction occurs. Do hospitals simply absorb these charge reductions and accept lower profit margins or do they cut costs in other ways? One concern might be that the overall quality of care is reduced. Preliminary results (not reported) suggest that mortality rates for the privately insured and uninsured/charitycare patients may be worsening, but further analysis is required. There are several other quality measures of interest such as the likelihood of relapse/hospital re-admittance, length of recovery time, level of investment in new technology/equipment, or presence of post discharge complications (i.e. infections). Unfortunately, the HCUP NIS does not have information on these quality measures so I leave this analysis for future work.

\section{References}

Aizer, Anna, \& Jeffrey Grogger, "Parental Medicaid Expansions and Child Medicaid Coverage," NBER Working Paper No. w9907, National Bureau of Economic Research, 2003.

American Hospital Association, "Fast Facts on US Hospitals" in AHA Hospital Statistics, ed. (Chicago, IL: Health Forum, LLC, 2015).

, "Appendix 4: Supplementary Data Tables, Trends in Hospital Financing, Table 4.4" in AHA Trendwatch Chartbook, 2014.

Beck, Melinda, "How to Bring the Price of Health Care into the Open: There's a Big Push to Tell Patients What They'll Pay - Before They Decide on Treatment" in The Wall Street Journal, 2014.

Blumberg, Linda J, Lisa Dubay \& Stephen A. Norton, "Did the Medicaid Expansions for Children Displace Private Insurance? An Analysis Using the SIPP," Journal of Health Economics, 19 (2000), 33-60.

Brown, Jeffrey R., Norma Coe, \& Amy Finkelstein, "Medicaid Crowd-out of Private Long-term Care Insurance Demand: Evidence from the Health and Retirement Survey," Tax Policy and the Economy, 21, (2007), 134.

Bruen, Brian.K., Joshua M. Wiener, Johnny Kim, \& Ossai Miazad, "State Usage of Medicaid Coverage Options for Aged Blind, and Disabled People," Assessing the New Federalism Discussion Papers, 1999.

Bruen, Brian K., Joshua M. Wiener \& Seema Thomas, "Medicaid Eligibility Policy for Aged, Blind, and Disabled Beneficiaries," The Urban Institute, 2003.

Journal of Health Economics, Vol. 49 (September 2016): pg. 46-58. DOI. This article is (C) Elsevier and permission has been granted for this version to appear in e-Publications@Marquette. Elsevier does not grant permission for this article to be further copied/distributed or hosted elsewhere without the express permission from Elsevier 
NOT THE PUBLISHED VERSION; this is the author's final, peer-reviewed manuscript. The published version may be accessed by following the link in the citation at the bottom of the page.

Card, David. \& Lara Shore-Sheppard, "Using Discontinuous Eligibility Rules to Identify the Effects of the Federal Medicaid Expansions on Low Income Children" Review of Economics and Statistics, 86, (2004), 752-766.

Centers for Disease Control and Prevention. "Chronic Diseases: The Leading Causes of Death and Disability in the United States," Chronic Disease Publications, 2014.

Centers for Medicare and Medicaid Services. (2014). "NHE Fact Sheet. National Health Expenditure Data," Research, Statistics, Data, and Systems: National Health Expenditure Data, 2014.

Clement, Jan P, "Dynamic Cost Shifting in Hospitals: Evidence from the 1980s and 1990s," Inquiry, 34, (1997), 340-350.

Christensen, Hans Bonde, Eric Floyd, \& Mark G. Maffett, (2013). "The Effect of Price Transparency Regulation on Prices in the Healthcare Industry," Chicago Booth Research Paper, 2013.

Coe, Norma B, "Financing Nursing Home Care: New Evidence on Spend-down Behavior," MIT Dissertation, 2005.

Congressional Research Service, Medicaid Source Book: Background Data and Analysis, (2003).

Cookson, J.P, "Further Discussion of High Hospital Charges. Society of Actuaries" Health Section News, 45, (2003), 24-25.

Cutler, David M, "Cost Shifting or Cost Cutting? The Incidence of Reductions in Medicare Payments," Tax Policy and the Economy, 12, (1998), 1-28.

, "The Incidence of Adverse Medical Outcomes Under Prospective Payment" Econometrica, 63, (1995), 29-50.

Cutler, David M. \& Jonathan Gruber, "Does Public Health Insurance Crowd-out Private Insurance?," Quarterly Journal of Economics, 111, (1996), 391-430.

Currie, Janet \& Jonathan Gruber, "Health Insurance Eligibility, Utilization of Medical Care, and Child Health," Quarterly Journal of Economics 111, (1996a), 431-466.

, "Saving Babies: The Efficacy and Cost of Recent Changes in the Medicaid Eligibility of Pregnant Women," Journal of Political Economy, 104, (1996b), 1263-1296.

De Nardi, Mariacristina, Eric French, John Bailey Jones, \& Angshuman Gooptu, "Medicaid and the Elderly," NBER Working Paper No. w17689, National Bureau of Economic Research, 2011.

Journal of Health Economics, Vol. 49 (September 2016): pg. 46-58. DOI. This article is (C) Elsevier and permission has been granted for this version to appear in e-Publications@Marquette. Elsevier does not grant permission for this article to be further copied/distributed or hosted elsewhere without the express permission from Elsevier 
NOT THE PUBLISHED VERSION; this is the author's final, peer-reviewed manuscript. The published version may be accessed by following the link in the citation at the bottom of the page.

Dobson, Allen, Joan DaVanzo, Julia Doherty,\& Myra Tanamor, "A Study of Hospital Charge Setting Practices," Lewin Group \& Medicare Payment Advisory Committee, (2005).

Dranove, David, "Pricing by Non Profit Institutions: The Case of Hospital Cost Shifting," Journal of Health Economics, 7, (1988), 47-57.

Dranove, David \& William D. White, "Medicaid Dependent Jospitals and Their Patients: How Have They Fared?," Health Services Research, 33, (1998), 163-185.

Dubay, Lisa C., \& Genevieve M. Kenney, "Revisiting the Issues: the Effects of Medicaid Expansions on Insurance Coverage of Children," The Future of Children 6, (1996), 152-161.

, "Did Medicaid Expansions for Pregnant Women Crowd-out Private Insurance?," Health Affairs 16, (1997), 185-193.

Fox, Will \& John Pickering, "Hospital and Physician Cost Shift: Payment Level Comparison of Medicare, Medicaid, and Commercial Payers," Milliman, (2008).

Frakt, Austin, "How Much Do Hospitals Cost Shift? A Review of the Evidence," The Milbank Quarterly, 89, (2011), 90-130.

Friesner, Daniel L. \& Robert Rosenman, "Cost Shifting Revisited: the Case of Service Intensity," Health Care Management Science, 5, (2002), 1524.

Garthwaite, Craig, "The Doctor Might See You Now: The Supply Side Effects of Public Health Insurance Expansions," American Economic Journal: Economic Policy, 4, (2012), 190-215.

George, Don, "Blue Cross Vermont CEO Don George: Cost Shift Nearly Tripled Since 2005 to $\$ 406$ Million," Vermontbiz, (2014).

Ginsburg, Paul B, "Can Hospitals and Physicians Shift the Effects of Cuts in Medicare Reimbursement to Private Payers?," Health Affairs, (2003), W3.

Glazer, Jacob. \& Thomas G. McGuire, "Multiple Payers, Commonality and Free-riding in Health Care: Medicare and Private Payers," Journal of Health Economics, 21, (2002), 1049-1069.

Gowrisankaran, Gautam, \& Robert J. Town, "Dynamic Equilibrium in the Hospital Industry," Journal of Economics \& Management Strategy, 6, (1997), 45-74.

Journal of Health Economics, Vol. 49 (September 2016): pg. 46-58. DOI. This article is (C) Elsevier and permission has been granted for this version to appear in e-Publications@Marquette. Elsevier does not grant permission for this article to be further copied/distributed or hosted elsewhere without the express permission from Elsevier. 
NOT THE PUBLISHED VERSION; this is the author's final, peer-reviewed manuscript. The published version may be accessed by following the link in the citation at the bottom of the page.

Gruber, Jonathan. \& Kosali Simon, "Crowd-out 10 Years Later: Have Recent Public Insurance Expansions Crowded Out Private Health Insurance?," Journal of Health Economics, 27, (2008), 201-217.

Ham, John C. \& Lara Shore-Sheppard, "The Effect of Medicaid Expansions for Low-Income Children on Medicaid Participation and Private Insurance Coverage: Evidence from the SIPP," Journal of Public Economics, 89, (2005), 57-83.

Hamersma, Sarah. \& Matthew Kim, "Participation and Crowd Out: Assessing the Effects of Parental Medicaid Expansions," Journal of Health Economics, 32, (2013), 160-171.

HCUP databases, "Introduction to the HCUP Nationwide Inpatient Sample (NIS)," Healthcare Cost and Utilization Project (HCUP), Agency for Healthcare Research and Quality, Rockville, MD, (2009).

HCUP Nationwide Inpatient Sample (NIS), Healthcare Cost and Utilization Project (HCUP), Agency for Healthcare Research and Quality, Rockville, MD, (1995-2007).

Herz, E., J. Hearne, J. Stone-Axelrad, K. Tritz, E. Baumrucker, C. Scott, C. Peterson, A. Grady, and R. Rimkunas, "CRS Report for Congress: How Medicaid Works - Program Basics. January 4, 2006 Update, Congressional Research Service," In The Library of Congress, (2006).

Hootman, J.M., Brault, M.W., Helmick,C.G., Theis, K.A., \& Armour, B.S. "Prevalence and most common causes of disability amoung adults United States, 2005." MMWR. 58(16), (2009), 421-426. http://www.cdc.gov/mmwr/preview/mmwrhtml/mm5816a2.htm?s_cid =mm5816a2_e Accessed November 9, 2015.

Horvath, Jane, "Medicaid Financial Eligibility for Aged, Blind, and Disabled: Survey of State Use of Selected Options," National Academy for State Health Policy, (1997).

Kaiser Commission on Medicaid and the Uninsured, "Medicaid Financial Eligibility: Primary Pathways for the Elderly and People with Disabilities" Kaiser Family Foundation, (2010).

Kassner, Enid \& Lee Shirley, "Medicaid Financial Eligibility for Older People: State Variations in Access to Home and Community-Based Waiver and Nursing Home Services," (Washington, DC: AARP Public Policy Institute, 2000).

King, M., S. Ruggles, J. Alexander, S. Flood, K. Genadek, M. Schroeder, B. Rampe, \& R. Vick, Integrated Public Use Microdata Series, Current Population Survey: Version 3.0. [Machine-readable database].

Journal of Health Economics, Vol. 49 (September 2016): pg. 46-58. DOI. This article is (C) Elsevier and permission has been granted for this version to appear in e-Publications@Marquette. Elsevier does not grant permission for this article to be further copied/distributed or hosted elsewhere without the express permission from Elsevier 
NOT THE PUBLISHED VERSION; this is the author's final, peer-reviewed manuscript. The published version may be accessed by following the link in the citation at the bottom of the page.

(Minneapolis, MN: Minnesota Population Center [producer and distributor], 2010).

McCown, D, "Health Care Reform Too Important To Rush, Boucher Tells Crowd," Bristol Herald Courier, (2009).

Mississippi Division of Medicaid, Annual Report, (1991-2008).

Morrisey, Michael, (1996). "Hospital Cost Shifting a Continuing Debate," EBRI Issue Brief, (1996).

Hudson, Julie L., Thomas M. Selden, \& Jessica S. Banthin, "The Impact of SCHIP on Insurance Coverage of Children," Inquiry 42, (2005), 232254.

LoSasso, A. \& T. Buchmueller, The Effect of the State Children's Health Insurance Program on Health Insurance Coverage. Journal of Health Economics 23, (2004), 1059-1082.

Shore-Sheppard, Lara D. "Stemming the tide? The effect of expanding Medicaid eligibility on health insurance." The B.E. Journal of Economic Analysis \& Policy 8, (2008), Article 6.

Showalter, Mark H., "Physicians' Cost Shifting Behavior: Medicaid Versus Other Patients," Contemporary Economic Policy 24, (1997), 11371144.

Sloan, Frank., Janet Mitchell, \& Jerry Cromwell, "Physician Participation in State Medicaid Programs," The Journal of Human Resources 13, (1978), 211-245.

Social Security Administration, Understanding Supplemental Security Income, (2012). , (1991-2008). "State Assistance Programs for SSI Recipients," SSA Publication No. 13-11975, (1991-2008).

Stensland, Jeffrey, Zachary R. Gaumer, \& Mark E. Miller, "Private-payers Profits Can Induce Negative Medicare Margins," Health Affairs 29, (2010), 1045-1051.

Stone, Julie Lynn, "Medicaid: Eligibility for the Aged and Disabled," (Washington, DC. Congressional Research Service, 2002).

, "Medicaid Eligibility for Persons Age 65+ and Individuals with Disabilities: 2009 State Profiles," (Washington, DC. Congressional Research Service, 2011).

Journal of Health Economics, Vol. 49 (September 2016): pg. 46-58. DOI. This article is (C) Elsevier and permission has been granted for this version to appear in e-Publications@Marquette. Elsevier does not grant permission for this article to be further copied/distributed or hosted elsewhere without the express permission from Elsevier. 
NOT THE PUBLISHED VERSION; this is the author's final, peer-reviewed manuscript. The published version may be accessed by following the link in the citation at the bottom of the page.

Thorpe, Kenneth E. \& Curtis S. Florence, "Health Insurance Coverage Among Children: the Role of Expanded Medicaid Coverage," Inquiry, 35, (1998), 369-379.

Truven Health Analytics: MarketScan Research Database, "Commercial Claims and Encounters," (Ann Arbor, MI. Truven Health Analytics, 20032004).

Turner, Grace-Marie. \& Avik Roy, "Why States Should Not Expand Medicaid," In Medicaid, ObamaCare, State Issues, The Galen Institute, (2013).

Wagner, Kathryn L., Medicaid Expansions For the Working Age Disabled: Revisiting the Crowd-out of Private Health Insurance," Journal of Health Economics, 40, (2015), 69-82.

White, Chapin, "Contrary to Cost-shift Theory, Lower Medicare Hospital Payment Rates for Inpatient Care Lead to Lower Private Payment Rates," Health Affairs 32, (2013), 935-943.

Wu, Vivian, "Hospital Cost Shifting Revisited: New Evidence from the Balanced Budget Act of 1997," International Journal of Health Care Finance and Economics, 10, (2010), 61-83.

Yazici, Esel Y., \& Robert Kaestner, "Medicaid Expansions and the Crowding out of Private Health Insurance Among Children," Inquiry 37(Spring 1), (2000), 23-32.

Zuckerman, S. \& D. Goin, "How Much Will Medicaid Physician Fees for Primary Care Rise in 2013? Evidence from a 2012 Survey of Medicaid Physician Fees," The Urban Institute, Kaiser Commission on Medicaid and the Uninsured, (2012).

Zwanziger, Jack, Glenn A. Melnick, \& Anil Bamezei, "Can Cost Shifting Continue in a Price Competitive Environment?," Health Economics, 9, (2000), 211-225.

Zwanziger, Jack, \& Anil Bamezei, "Evidence of Cost Shifting in California Hospitals," Health Affairs, 15, (2006), 197-203.

Journal of Health Economics, Vol. 49 (September 2016): pg. 46-58. DOI. This article is (C) Elsevier and permission has been granted for this version to appear in e-Publications@Marquette. Elsevier does not grant permission for this article to be further copied/distributed or hosted elsewhere without the express permission from Elsevier. 
NOT THE PUBLISHED VERSION; this is the author's final, peer-reviewed manuscript. The published version may be accessed by following the link in the citation at the bottom of the page.

Table I: Summary Statistics for Working Age Men with At Least One Chronic Condition in HCUP NIS Sample Top 100 Primary Diagnosis Codes

\begin{tabular}{lcc}
\hline \hline Variable & Mean & $\begin{array}{c}\text { Standard } \\
\text { Deviation }\end{array}$ \\
\hline Average Age & 49 & 10.92 \\
\% Black & 0.19 & 0.39 \\
\% Hispanic & 0.09 & 0.29 \\
\% Native American & 0.004 & 0.06 \\
\% Pacific Islander or Asian & 0.01 & 0.12 \\
Average Real Charges & $\$ 26,279$ & $\$ 42,209$ \\
\% Medicaid & 0.19 & 0.39 \\
\% Medicare & 0.21 & 0.41 \\
\% Private & 0.49 & 0.50 \\
\% Uninsured/Charity & 0.12 & 0.32 \\
Average Length of Stay (Days) & 5.21 & 7.53 \\
Observations (Discharges) & & \\
\hline \hline
\end{tabular}

Notes: Summary statistics are weighted using the discharge weight constructed by the HCUP NIS. Charges are in 2007 real dollars

Table II: Top 5 Primary Diagnoses Working Age Men with one Chronic Condition in the HCUP NIS 1995-2007

\begin{tabular}{lll}
\hline $\begin{array}{l}\text { Diagnosis } \\
\text { Code }\end{array}$ & Description & $\begin{array}{l}\text { Number of } \\
\text { Discharges (\% of } \\
\text { Sample Cases) }\end{array}$ \\
\hline 41401 & Coronary Atherosclerosis (Native Vessel) & $513,107(10.56 \%)$ \\
4280 & Congestive Heart Failure & $223,573(4.60 \%)$ \\
78659 & Chest Pain & $182,198(3.75 \%)$ \\
486 & Pneumonia & $178,737(3.68 \%)$ \\
41071 & Subendocardial Infarction & $137,033(2.82 \%)$ \\
\hline
\end{tabular}

Notes: Diagnosis codes follow the ICD-9-CM strategy.

Journal of Health Economics, Vol. 49 (September 2016): pg. 46-58. DOI. This article is @ Elsevier and permission has been granted for this version to appear in e-Publications@Marquette. Elsevier does not grant permission for this article to be further copied/distributed or hosted elsewhere without the express permission from Elsevier. 
Table III: Medicaid Upper Income Threshold (UIT) and Simulated Eligibility for States in HCUP NIS First and Last Years in Sample

\begin{tabular}{|c|c|c|c|c|c|}
\hline \multirow[b]{2}{*}{ State } & \multirow[b]{2}{*}{$\begin{array}{c}\text { First Year in } \\
\text { Sample }\end{array}$} & \multicolumn{2}{|c|}{ First Year } & \multicolumn{2}{|c|}{ Last Year (2007) } \\
\hline & & $\begin{array}{c}\text { UIT } \\
(\% \text { FPL })\end{array}$ & $\begin{array}{l}\text { Simulated } \\
\text { Eligibility }\end{array}$ & $\begin{array}{c}\text { UIT } \\
(\% \text { FPL })\end{array}$ & $\begin{array}{l}\text { Simulated } \\
\text { Eligibility }\end{array}$ \\
\hline $\mathrm{AR}$ & 2004 & 80 & 0.43 & 80 & 0.43 \\
\hline $\mathrm{AZ}$ & 1995 & 74 & 0.40 & 100 & 0.50 \\
\hline $\mathrm{CA}$ & 1995 & 99 & 0.48 & 102 & 0.51 \\
\hline $\mathrm{CO}$ & 1995 & 83 & 0.41 & 77 & 0.41 \\
\hline $\mathrm{CT}$ & 1995 & 121 & 0.55 & 94 & 0.48 \\
\hline FL & 1995 & 90 & 0.44 & 88 & 0.46 \\
\hline $\mathrm{HI}$ & 1997 & 115 & 0.53 & 115 & 0.55 \\
\hline IA & 1995 & 74 & 0.37 & 74 & 0.40 \\
\hline IN & 2003 & 74 & 0.41 & 74 & 0.40 \\
\hline $\mathrm{KS}$ & 1995 & 74 & 0.37 & 74 & 0.40 \\
\hline MA & 1995 & 133 & 0.60 & 133 & 0.60 \\
\hline $\mathrm{MD}$ & 1995 & 74 & 0.37 & 74 & 0.40 \\
\hline MI & 2003 & 100 & 0.50 & 100 & 0.50 \\
\hline $\mathrm{MO}$ & 1995 & 74 & 0.36 & 85 & 0.45 \\
\hline $\mathrm{NC}$ & 2000 & 74 & 0.37 & 100 & 0.50 \\
\hline NE & 2005 & 100 & 0.50 & 100 & 0.50 \\
\hline $\mathrm{NH}$ & 2003 & 78 & 0.42 & 77 & 0.41 \\
\hline NJ & 1995 & 100 & 0.48 & 100 & 0.50 \\
\hline NY & 1995 & 88 & 0.43 & 84 & 0.45 \\
\hline $\mathrm{OK}$ & 2005 & 100 & 0.50 & 100 & 0.50 \\
\hline PA & 1995 & 100 & 0.48 & 100 & 0.50 \\
\hline $\mathrm{RI}$ & 2001 & 100 & 0.48 & 100 & 0.50 \\
\hline SC & 1995 & 100 & 0.48 & 100 & 0.50 \\
\hline $\mathrm{SD}$ & 2002 & 76 & 0.39 & 76 & 0.41 \\
\hline $\mathrm{TN}$ & 1997 & 74 & 0.38 & 74 & 0.40 \\
\hline TX & 2000 & 74 & 0.37 & 74 & 0.40 \\
\hline UT & 2002 & 100 & 0.49 & 100 & 0.50 \\
\hline $\mathrm{VA}$ & 1999 & 74 & 0.37 & 80 & 0.43 \\
\hline VT & 2001 & 100 & 0.48 & 80 & 0.43 \\
\hline WY & 2007 & 74 & 0.40 & 74 & 0.40 \\
\hline
\end{tabular}

Notes: The Upper Income Threshold (UIT) is the maximum amount of income as a percent of the Federal Poverty Level (FPL) that an individual is allowed to have and still qualify for Medicaid coverage. Simulated Eligibility is constructed as the share of a national sample that would be eligible for Medicaid if a state's eligibility standards were imposed on the entire country. UIT and Simulated Eligibility are reported for the first year a state enters the constructed sample and in 2007 (the last year of the study period). 
NOT THE PUBLISHED VERSION; this is the author's final, peer-reviewed manuscript. The published version may be accessed by following the link in the citation at the bottom of the page.

Table IV: Effects of Simulated Eligibility on Insurance Type for Hospitals from HCUP NIS 1995-2007: Top 100 Primary Diagnoses for Working Age Men with At Least One Chronic Condition

\begin{tabular}{lcccc}
\hline \hline & Private & Medicaid & Medicare & $\begin{array}{c}\text { Uninsured/Charity } \\
\text { Covariates }\end{array}$ \\
\hline Simulated Eligibility & $-0.348^{* * *}$ & $0.298^{* *}$ & -0.016 & 0.066 \\
& $(0.092)$ & $(0.116)$ & $(0.048)$ & $(0.127)$ \\
& & & & \\
Mean(Payer Type) & 0.49 & 0.19 & 0.21 & 0.11 \\
\# of Cells & $3,672,037$ & $3,672,037$ & $3,672,037$ & $3,672,037$ \\
R-squared & 0.2670 & 0.1981 & 0.1222 & 0.1314 \\
\hline \hline
\end{tabular}

Notes: Results are for the top 100 primary diagnosis codes for working age men with at least one chronic condition in the HCUP NIS. The dependent variables are indicator variables for four insurance types: Private Insurance, Medicaid, Medicare, and Uninsured/Charity Care. All regressions control for Hospital, Year, Quarter, Diagnosis, Race, Age Category, and Duration of Stay Category Fixed Effects. Regressions are weighted using the discharge weight constructed by the HCUP NIS and standard errors are clustered at the state level. * represents a 10 percent significance level, ** represents a 5 percent significance level, and $* * *$ represents a 1 percent significance level.

Table V: Effects of Simulated Eligibility on Log Charge Rate by Insurance Type for Hospitals from HCUP NIS 1995-2007: Top 100 Primary Diagnoses for Working Age Men with At Least One Chronic Condition

\begin{tabular}{lcccc}
\hline \hline Covariates & Private & Medicaid & Medicare & $\begin{array}{c}\text { Uninsured/Charity } \\
(4)\end{array}$ \\
\hline Simulated Eligibility & $(1)$ & $(2)$ & $(3)$ & 1.315 \\
& $(0.554)$ & $(0.711)$ & $(0.439)$ & $(1.836)$ \\
& & & & \\
Mean(Payment Rate) & $\$ 27,427$ & $\$ 24,805$ & $\$ 26,989$ & $\$ 21,224$ \\
\# of Cells & $1,613,488$ & 727,295 & 860,917 & 470,337 \\
R-squared & 0.7563 & 0.7786 & 0.7435 & 0.7526 \\
\hline \hline
\end{tabular}

Notes: Results are for the top 100 primary diagnosis codes for working age men with at least one chronic condition in the HCUP NIS. Regressions are for four insurance types: Private Insurance, Medicaid, Medicare, and Uninsured/Charity Care. The payment rate is constructed as the average charges per patient by insurance type. All regressions control for Hospital, Year, Quarter, Diagnosis, Race, Age Category, and Duration of Stay Category Fixed Effects. Regressions are weighted using the discharge weight constructed by the HCUP NIS and standard errors are clustered at the state level. * represents a 10 percent significance level, ** represents a 5 percent

Journal of Health Economics, Vol. 49 (September 2016): pg. 46-58. DOI. This article is (C) Elsevier and permission has been granted for this version to appear in e-Publications@Marquette. Elsevier does not grant permission for this article to be further copied/distributed or hosted elsewhere without the express permission from Elsevier. 
NOT THE PUBLISHED VERSION; this is the author's final, peer-reviewed manuscript. The published version may be accessed by following the link in the citation at the bottom of the page.

significance level, and $* * *$ represents a 1 percent significance level. The charge rate is constructed by dividing total aggregate charges by total discharges in a cell.

Table VI: Effects of Simulated Eligibility on Insurance Type for Hospitals from HCUP NIS 1995-2007: Working Age Men with No Chronic Diagnoses

\begin{tabular}{lcccc}
\hline \hline Covariates & Private & Medicaid & Medicare & $\begin{array}{c}\text { Uninsured/Charity } \\
(4)\end{array}$ \\
\hline Sim. Eligibility & $(1)$ & $(2)$ & $(3)$ & 0.191 \\
& $(0.239$ & 0.049 & -0.001 & $(0.211)$ \\
& & $(0.111)$ & $(0.028)$ & 0.22 \\
Mean(Payer Type) & 0.63 & 0.10 & 0.04 & $1,514,597$ \\
\# of Cells & $1,514,597$ & $1,514,597$ & $1,514,597$ & 0.2067 \\
R-squared & 0.2277 & 0.1446 & 0.0623 & \\
\hline \hline
\end{tabular}

Notes: Results are for working age men with no chronic condition in the HCUP NIS. The dependent variables are indicator variables for four insurance types: Private Insurance, Medicaid, Medicare, and Uninsured/Charity Care. All regressions control for Hospital, Year, Quarter, Diagnosis, Race, Age Category, and Duration of Stay Category Fixed Effects. Regressions are weighted using the discharge weight constructed by the HCUP NIS and standard errors are clustered at the state level. * represents a 10 percent significance level, $* *$ represents a 5 percent significance level, and $* * *$ represents a 1 percent significance level.

Table VII: Effects of Simulated Eligibility on Log Charges per Day by Insurance Type for Hospitals from HCUP NIS 1995-2007: Top 100 Primary Diagnoses for Working Age Men with At Least One Chronic Condition

\begin{tabular}{lcccc}
\hline Covariates & $\begin{array}{c}\text { Private } \\
(1)\end{array}$ & $\begin{array}{c}\text { Medicaid } \\
(2)\end{array}$ & $\begin{array}{c}\text { Medicare } \\
(3)\end{array}$ & $\begin{array}{c}\text { Uninsured/Charity } \\
(4)\end{array}$ \\
\hline Simulated Eligibility & $-0.993^{*}$ & -0.111 & -0.389 & 1.438 \\
& $(0.500)$ & $(0.651)$ & $(0.452)$ & $(1.804)$ \\
& & & & \\
Mean(Chg. Per Day) & $\$ 7,930$ & $\$ 4,520$ & $\$ 5,380$ & $\$ 5,452$ \\
\# of Cells & $1,384,078$ & 616,184 & 736,596 & 435,811 \\
R-squared & 0.7413 & 0.7287 & 0.7007 & 0.7051 \\
\hline \hline
\end{tabular}

Notes: Results are for the top 100 primary diagnosis codes for working age men with at least one chronic condition in the HCUP NIS. Regressions are for four insurance types: Private Insurance, Medicaid, Medicare, and Uninsured/Charity Care. The payment rate is constructed as the average charges per patient by insurance type. All regressions control for Hospital, Year, Quarter, Diagnosis, Race, and Age Category Fixed Effects. Regressions

Journal of Health Economics, Vol. 49 (September 2016): pg. 46-58. DOI. This article is (C) Elsevier and permission has been granted for this version to appear in e-Publications@Marquette. Elsevier does not grant permission for this article to be further copied/distributed or hosted elsewhere without the express permission from Elsevier. 
are weighted using the discharge weight constructed by the HCUP NIS and standard errors are clustered at the state level. * represents a 10 percent significance level, $* *$ represents a 5 percent significance level, and $* * *$ represents a 1 percent significance level. The charge rate is constructed by dividing total aggregate charges by total days spent in the hospital in a cell.

Table VIII: Effects on Insurance Type and Log(Charge Rate) for Hospitals from HCUP NIS 1995-2007: Top 50 and 500 Primary Diagnoses for Working Age Men with At Least One Chronic Condition

\begin{tabular}{|c|c|c|c|c|}
\hline Covariates & $\begin{array}{l}\text { Private } \\
\text { (1) }\end{array}$ & $\begin{array}{c}\text { Medicaid } \\
(2)\end{array}$ & $\begin{array}{c}\text { Medicare } \\
\text { (3) }\end{array}$ & $\begin{array}{c}\text { Uninsured/Charity } \\
\text { (4) }\end{array}$ \\
\hline & \multicolumn{4}{|c|}{ Panel A: Top 50 Diagnosis Codes } \\
\hline & \multicolumn{4}{|c|}{ I: Insurance Type } \\
\hline \multirow[t]{2}{*}{ Sim. Eligibility } & $-0.328^{* * *}$ & $0.294^{* *}$ & -0.004 & 0.038 \\
\hline & $(0.091)$ & $(0.108)$ & $(0.055)$ & $(0.123)$ \\
\hline Mean(Payer Type) & 0.49 & 0.19 & 0.21 & 0.11 \\
\hline \# of Cells & $2,742,211$ & $2,742,211$ & $2,742,211$ & $2,742,211$ \\
\hline \multirow[t]{2}{*}{ R-squared } & 0.2717 & 0.1979 & 0.1237 & 0.1229 \\
\hline & \multicolumn{4}{|c|}{ II: Log(Charge Rate) } \\
\hline \multirow[t]{2}{*}{ Sim. Eligibility } & $-1.306 * *$ & -0.112 & -0.565 & 1.471 \\
\hline & $(0.601)$ & $(0.727)$ & $(0.470)$ & $(1.913)$ \\
\hline Mean (Pay Rate) & $\$ 28,006$ & $\$ 25,601$ & $\$ 27,436$ & $\$ 22,395$ \\
\hline \# of Cells & $1,167,824$ & 557,078 & 672,758 & 344,551 \\
\hline \multirow[t]{3}{*}{ R-squared } & 0.7700 & 0.7842 & 0.7513 & 0.7630 \\
\hline & \multicolumn{4}{|c|}{ Panel B: Top 500 Diagnosis Codes } \\
\hline & \multicolumn{4}{|c|}{ I: Insurance Type } \\
\hline \multirow[t]{2}{*}{ Sim. Eligibility } & $-0.308^{* * * *}$ & $0.292^{* * *}$ & -0.031 & 0.047 \\
\hline & $(0.083)$ & $(0.118)$ & $(0.039)$ & $(0.129)$ \\
\hline Mean(Payer Type) & 0.49 & 0.19 & 0.21 & 0.11 \\
\hline \# of Cells & $5,864,253$ & $5,864,253$ & $5,864,253$ & $5,864,253$ \\
\hline \multirow[t]{2}{*}{ R-squared } & 0.2539 & 0.1817 & 0.1182 & 0.1335 \\
\hline & \multicolumn{4}{|c|}{ II: $\log ($ Charge Rate) } \\
\hline Sim. Eligibility & $-1.104^{* *}$ & -0.111 & -0.592 & 0.872 \\
\hline & $(0.516)$ & $(0.677)$ & $(0.432)$ & $(1.665)$ \\
\hline Mean(Pay Rate) & $\$ 28,485$ & $\$ 26,579$ & $\$ 28,301$ & $\$ 22,140$ \\
\hline \# of Cells & $2,670,563$ & $1,113,161$ & $1,364,157$ & 716,372 \\
\hline R-squared & 0.7444 & 0.7766 & 0.7412 & 0.7506 \\
\hline
\end{tabular}

Notes: Results are for the top 50 (Panel A) and top 500 (Panel B) primary diagnosis codes for working age men with at least one chronic condition in the HCUP NIS. The dependent variables in the Insurance Type Analyses (I) are indicator variables for four insurance types: Private, Medicaid, Medicare, and Self-pay/Charity. The dependent variable for Log(Charge Rate) (II) is 
constructed as the log of the total aggregate charges divided by total discharges in a cell for a given insurance type. All regressions control for Hospital, Year, Quarter, Diagnosis, Race, Age Category, and Duration of Stay Category Fixed Effects. Regressions are weighted using the discharge weight constructed by the HCUP NIS and standard errors are clustered at the state level. * represents a 10 percent significance level, ** represents a 5 percent significance level, and $* * *$ represents a 1 percent significance level.

Figure I: Aggregate Hospital Payment-to-Cost Ratio, by Insurance Type, 1992-2012

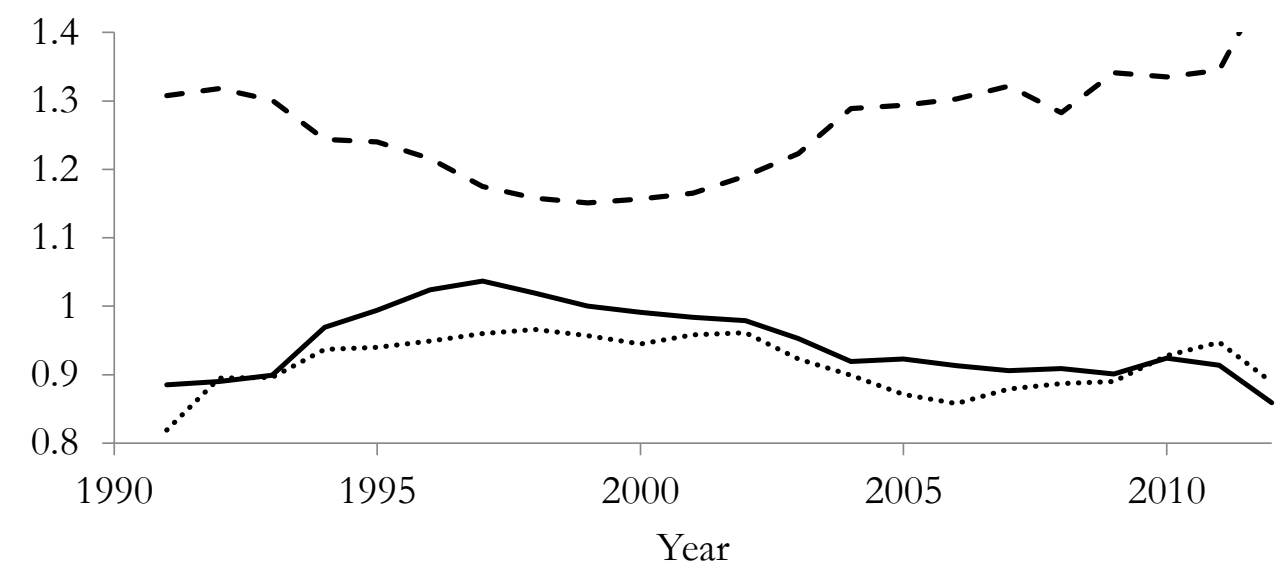

— Medicare .......... Medicaid - - - Private

Notes: Data sourced from the American Hospital Association's Trendwatch Chartbook 2014, Table 4. The figure includes a time series from 1992 to 2012 of aggregate total payments relative to the total costs required to treat private, Medicaid, and Medicare patients for US hospitals. Payments include Medicare and Medicaid Disproportionate Share payments.

Journal of Health Economics, Vol. 49 (September 2016): pg. 46-58. DOI. This article is (C) Elsevier and permission has been granted for this version to appear in e-Publications@Marquette. Elsevier does not grant permission for this article to be further copied/distributed or hosted elsewhere without the express permission from Elsevier. 
NOT THE PUBLISHED VERSION; this is the author's final, peer-reviewed manuscript. The published version may be accessed by following the link in the citation at the bottom of the page.

Figure II: Graphical Representation of the Mixed Economy Model

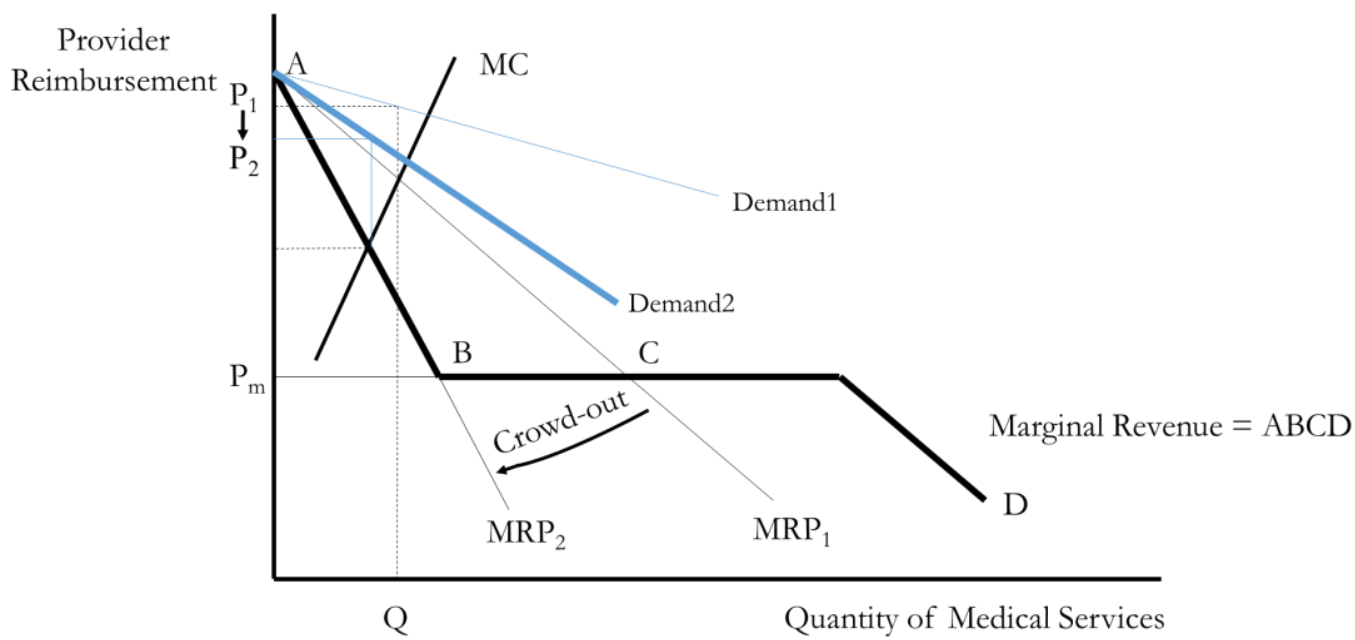

Notes: In a mixed economy model, hospitals face two markets: a price setting market represented by downward sloping demands corresponding to marginal revenue curves $\mathrm{MRP}_{1}$ and later $\mathrm{MRP}_{2}$ and a government reimbursed market represented by a horizontal line at the public reimbursement rate $\mathrm{P}_{\mathrm{m}}$. When crowd-out occurs in a Medicaid expansion, $\mathrm{MRP}_{1}$ rotates to $\mathrm{MRP}_{2}$ and the price for a hospital with marginal cost curve $M C$ decreases from $P_{1}$ to $P_{2}$.

\section{Appendix}

\section{A.1: Pre and Post Expansion Trends}

The key outcomes are a set of measures of coverage rates at the state-year level of the four forms of insurance listed in Table A.1. I then regress these coverage rates on state and year effects plus two variables that measure the pre- and post-adoption trends for the states. The pre-adoption trend is constructed as a negative integer that indicates the number of years until an expanding state's adoption and zero for non-adopting states or for years after a state adopted. The post-adoption trend variable is constructed as a positive integer that indicates the number of years after an expanding state's adoption and zero for non-adopting states or for years prior to a state's adoption. $^{21}$

The regression results for the pre-treatment analysis are presented in Table A.1. I find no statistically significant difference in coverage rates between adopting and non-adopting states leading up to the expansions. The pre-adoption trend coefficients in Table A.1 are near zero and statistically

${ }^{21}$ I group all observations with a pre-trend value less than or equal to -9 into one category. I also group all observations with a post-trend value greater than or equal to 9 into one category.

Journal of Health Economics, Vol. 49 (September 2016): pg. 46-58. DOI. This article is (C Elsevier and permission has been granted for this version to appear in e-Publications@Marquette. Elsevier does not grant permission for this article to be further copied/distributed or hosted elsewhere without the express permission from Elsevier. 
NOT THE PUBLISHED VERSION; this is the author's final, peer-reviewed manuscript. The published version may be accessed by following the link in the citation at the bottom of the page.

insignificant for all four types of insurance coverage implying little coverage differences between adopting and non-adopting states. There is a statistically significant difference between Medicaid and private insurance rates postadoption, however, and the coefficients on the post-adoption trend variable indicate the presence of crowd-out. States who adopted the expansions saw increases in their Medicaid rates and decreases in their private insurance rates relative to non-adopting states though the magnitudes of the coefficients are not exactly equal. Overall, the results in Table A.1 indicate the similarity of coverage rates trends prior to expansion and supports the validity of the instrument, but this is by no means a sufficient condition for no endogeneity.

Table A.1: Pre and Post Trends in State Insurance Coverage Rates Work Disabled Sample 1992-2008 March CPS

\begin{tabular}{lcccc}
\hline \hline & $\begin{array}{c}\text { Medicaid } \\
(1)\end{array}$ & $\begin{array}{c}\text { Private } \\
(2)\end{array}$ & $\begin{array}{c}\text { Medicare } \\
(3)\end{array}$ & $\begin{array}{c}\text { Uninsurance } \\
(4)\end{array}$ \\
\cline { 2 - 5 } & & & & \\
Pre-Adoption Trend & 0.0005 & 0.0003 & -0.0004 & 0.0008 \\
& $(0.0020)$ & $(0.0015)$ & $(0.0011)$ & $(0.0013)$ \\
Post-Adoption Trend & $0.0048^{* * *}$ & $-0.0035^{*}$ & 0.0006 & -0.0001 \\
& $(0.0017)$ & $(0.0019)$ & $(0.0010)$ & $(0.0012)$ \\
& & & & \\
Mean(Ins. Rate) & 0.31 & 0.44 & 0.27 & 0.14 \\
Observations & 867 & 867 & 867 & 867 \\
R-squared & 0.7240 & 0.6766 & 0.6621 & 0.5885 \\
\hline \hline
\end{tabular}

Notes: Results are from the 1992-2008 March CPS for work disabled individuals between the ages of 20 and 64. Regressions are OLS regressions of four types of state insurance coverage rates (Medicaid, Private, Medicare, and Uninsured) on a preadoption trend and a post-adoption trend. All regressions control for state and year fixed effects. Standard errors are clustered at the state level. * represents a $10 \%$ significance level, ** represents a $5 \%$ significance level, and $* * *$ represents a $1 \%$ significance level. All regressions are weighted using the SHADAC constructed weight for CPS health insurance coverage.

\section{A.2: Models of Cost-Shifting}

There are two main threads of literature that focus on modeling hospital pricing behavior with regards to cost shifting. Both threads assume that the hospital is faced with two types of insurance: a higher priced private market and a lower priced public alternative. This two-market model has been commonly referred to as a mixed economy model and was originally discussed in Sloan et al. (1978) as a way of modeling physician participation in the Medicaid program. Using these models, we form predictions as to how hospitals respond to a shock in provider revenue, usually originating from a change to the public insurance reimbursement rate.

Journal of Health Economics, Vol. 49 (September 2016): pg. 46-58. DOI. This article is (C Elsevier and permission has been granted for this version to appear in e-Publications@Marquette. Elsevier does not grant permission for this article to be further copied/distributed or hosted elsewhere without the express permission from Elsevier. 
NOT THE PUBLISHED VERSION; this is the author's final, peer-reviewed manuscript. The published version may be accessed by following the link in the citation at the bottom of the page.

The first thread of the cost-shifting literature assumes that hospitals behave as profit maximizers either as a monopolist or a firm with some degree of market power. In standard market models, if a hospital is profit maximizing, cost-shifting strategies would not be employed. Profit maximizing firms should have already exhausted their market power and further price discrimination is not possible, eliminating the ability to cost shift onto private payers (Morrisey 1996). In response to lower public payments, profit maximizing health care providers may choose to accept fewer public paying patients (Showalter, 1997). This would be challenging for hospitals since most are legally mandated to admit any patient who arrives requiring care. Hospitals would like to serve more private patients than public patients, however, since they are reimbursed more per private patient. Thus, in order to attract more private patients to use their facility, profit maximizing hospitals will lower private prices (Showalter 1997). The new private price will still be higher than the public reimbursement rate. This is the opposite of what cost-shifting theory would suggest.

A prediction from the profit maximization assuming models is that when the public reimbursement rate is reduced, the private rate should also decrease. That is, we would expect to see a positive correlation between Medicaid and private reimbursement rates. Time series trends in private and public health prices run counter to this prediction, however. Figure I plots the aggregate hospital payment-to-cost ratios for private, Medicare, and Medicaid insurance in the United States from 1992 to 2012.22 As the private paymentto-cost ratio falls in the late 1990s, the public payment-to-cost ratios rise and in the early 2000s when private rates rise again, the public rates decline. The trends documented in Figure I demonstrate a negative correlation between private and public hospital payments but this is at best only suggestive evidence against the profit maximizing assumption.

The second thread of the cost shifting literature does not assume profit maximizing behavior and instead focuses on hospitals behaving as utility maximizers. A primary motive for this is that only 18 percent of US hospitals in 2011 were investor-owned (for-profit) (American Hospital Association 2013). Not-for-profit hospitals typically have no shareholders so any profits generated are used to fund hospital operations or projects such as capital improvement or charity care. Many not-for-profit hospitals have mission statements that indicate they seek to meet community needs, provide care to as many patients as possible, and advance treatment and means of prevention (Ginsburg 2003). As a result, it is often thought that not-for-profit hospitals maximize a utility function with profit margin and

\footnotetext{
${ }^{22}$ The hospital payment-to-cost ratios are from the American Hospital Association's Trendwatch Chartbook.
}

Journal of Health Economics, Vol. 49 (September 2016): pg. 46-58. DOI. This article is (C) Elsevier and permission has been granted for this version to appear in e-Publications@Marquette. Elsevier does not grant permission for this article to be further copied/distributed or hosted elsewhere without the express permission from Elsevier. 
NOT THE PUBLISHED VERSION; this is the author's final, peer-reviewed manuscript. The published version may be accessed by following the link in the citation at the bottom of the page.

alternative objectives (usually identified within their mission statements) as arguments.

One of the biggest challenges of the utility maximization approach is determining which alternative objectives in addition to profits should be included when modeling the hospital's utility function. Frakt (2011) provides an excellent review of the utility maximizing literature which I will briefly describe below. Several studies assume that there are only two arguments in a hospital's utility function: profits and the total volume of medical services provided to the hospital's community (Dranove 1988; Clement 1997; and Zwanziger, Melnick, and Bamezai 2000). These studies find that utility maximization models, unlike the profit maximizing assuming models, allow for the possibility of cost shifting but do not guarantee that cost-shifting will occur. Other studies assume that utility maximizing hospitals care about their overall appearance to the community or their "prestige" (Rosenman et al. 2000; and Friesner and Rosenman 2002). The Rosenman et al. (2000) model shows that prestige maximizing hospitals can either cost shift or cost cut in response to reductions in public payments.

The two threads of literature produce conflicting theoretical predictions. It is clear that while profit maximization suggests the impossibility of cost shifting, utility maximization implies that cost shifting may occur. Given these conflicting theoretical results, there have been several empirical attempts to determine whether cost shifting exists in the U.S. health care market. These studies focus not only on whether hospitals cost shift, but also to what extent cost shifting occurs. Provided that hospitals shift the burden of the reductions in public payments onto private payers, they may do this dollar-for-dollar or at some lower rate. The majority of the empirical literature finds that the extent of cost shifting is far less than dollar-for-dollar. ${ }^{23}$ Only Cutler (1998) found evidence of dollar-for-dollar cost shifting and this was restricted to the $1985-1990$ time period. ${ }^{24}$

Though a large portion of cost shifting literature was published in the late 1990 s to early 2000 s, even more recent empirical cost-shifting articles still produce conflicting results. Wu (2010) finds evidence of cost-shifting in Medicare payment reductions stipulated by the Balanced Budget Act of 1997, though the degree of cost-shifting is relatively small (only 21 cents per dollar

${ }^{23}$ Several empirical studies attempt to measure the extent of hospital cost shifting empirically. Studies include Clement (1997), Gowrisankaran and Town (1997), Cutler (1998), Dranove and White (1998), Zwanziger et al. (2000), Friesner and Rosenman (2002), Dobson et al. (2006), Zwanziger and Bamezai (2006), Wu (2010), and Stensland et al. (2010). These are effectively summarized in Frakt (2011), Table 2.

${ }^{24}$ In the same study, he finds very little evidence of cost shifting from 1990 to 1995 speculating this as being a result of increased managed care use during this time period.

Journal of Health Economics, Vol. 49 (September 2016): pg. 46-58. DOI. This article is (C) Elsevier and permission has been granted for this version to appear in e-Publications@Marquette. Elsevier does not grant permission for this article to be further copied/distributed or hosted elsewhere without the express permission from Elsevier. 
NOT THE PUBLISHED VERSION; this is the author's final, peer-reviewed manuscript. The published version may be accessed by following the link in the citation at the bottom of the page.

reduction in Medicare revenue was shifted onto private payers). White (2013) constructs private and Medicare payment rates at a market level for the years 1995-2009. Using a "log-log" specification, the results from White (2013) indicate that a 10 percent reduction in the Medicare rate, led to a 7.73 percent reduction in the private rate. White's results suggest that hospitals did not pursue cost-shifting, but rather cost-cutting strategies to make up for the deficit between private and public rates. Thus, even the most recent empirical estimates still provide mixed results regarding the existence of cost shifting in the US health care market.

\section{A.3 Charges versus Prices/Payments}

The HCUP NIS contains the total charges for each discharge which is not necessarily equal to the actual payments the hospital received for the services it provided. The terms prices and charges are often used interchangeably, but in general refer to two distinct variables. Charges are usually understood to be the list price of a service provided at the hospital while prices usually refer to the actual payment that hospitals/providers received from the insurer (after rates have been negotiated). It is widely believed that charges are irrelevant, marked-up versions of prices and are not informative of current hospital cost conditions or behavior. Several studies, however, have indicated that charges may not be completely irrelevant particularly in regards to the setting of Medicare reimbursement rates, price transparency, uninsured/out-of-network patients, and inpatient outlier provision patients (Cookson, 2003, Dobson et al., 2005, Christensen et al., 2013.).

Actual payments and prices would be preferred over charges when investigating effects on cost-shifting. Data sets containing actual payments from all insurance types, over long periods of time, for multiple states, and at the patient level, however, are rare and expensive. The question remains then as to how informative total charges are in regards to payments? To evaluate this issue, I obtained the MarketScan Commercial Claims and Encounters (CCE) database from Truven Health Analytics, Inc. for the years 2003 and 2004. The CCE contains claims (actual payments) data from a selection of large employer-provided plans in the United States for various encounter environments (Inpatient, Outpatient, Pharmaceuticals, etc.). Using the inpatient encounters data, we can compare charges in the HCUP NIS and the claims in the CCE and examine how informative one is of the other.

First, I have to create comparable samples between the CCE and the NIS. In order to align the CCE with my study sample, I eliminate claims for patients who are not between the ages of 20 to 64 or who are female. Since the CCE contains commercial claims, I restrict the HCUP NIS to only include

Journal of Health Economics, Vol. 49 (September 2016): pg. 46-58. DOI. This article is C Elsevier and permission has been granted for this version to appear in e-Publications@Marquette. Elsevier does not grant permission for this article to be further copied/distributed or hosted elsewhere without the express permission from Elsevier. 
NOT THE PUBLISHED VERSION; this is the author's final, peer-reviewed manuscript. The published version may be accessed by following the link in the citation at the bottom of the page.

patients covered by private insurance in the years 2003 and 2004. Given that there is no direct link between the patients in the two datasets, I calculate the average total charges from the NIS and average total payments from the CCE for each state-year-DRG cell and then merge the two databases based on these three characteristics. Merging based on state, year, and DRG ensures that we are making charge and payment comparisons for patients with similar geographic, time, and medical conditions.

A disadvantage to this analysis is that the CCE only includes individuals with employer-provided coverage from large firms while the HCUP NIS includes a general census of inpatient discharges in the United States. Thus, even though we match charges and payments based on three influential characteristics, it is likely that the general population from the NIS contains individuals who have less comprehensive private plans than those from the large employer-provided population of the CCE. Figure is a scatterplot of the matched charges and payments from the two datasets along with a 45 degree line. The scatterplot suggests that there is an informative relationship, all-be-it a noisy one, between the charges of the HCUP NIS and the payments contained within the MarketScan CCE. The scatterplot also suggests that the degree of mismeasurement between charges and payments increases with the level of charges which is unsurprising given the results of other studies that have compared actual claims to list prices.

The relationship can be further evaluated using a regression analysis. Estimates of a regression of the average payments on the average charges imply that for every dollar increase in average charges, average payments increases by 0.61 and 0.67 with and without state and year fixed effects, respectively. Though there is clearly measurement error between charges and payments, the important takeaway is that there is a fairly informative relationship between the two. Given this, the estimates of the impact of the insurance shift on the charge rate can give us an idea of the effect on actual payments though actual payments would be require to estimate an exact effect.

Journal of Health Economics, Vol. 49 (September 2016): pg. 46-58. DOI. This article is (C) Elsevier and permission has been granted for this version to appear in e-Publications@Marquette. Elsevier does not grant permission for this article to be further copied/distributed or hosted elsewhere without the express permission from Elsevier. 
Figure A.3: Relationship between HCUP Charges and Market Scan Payments, Top 100 DRG's with 45 Degree Line

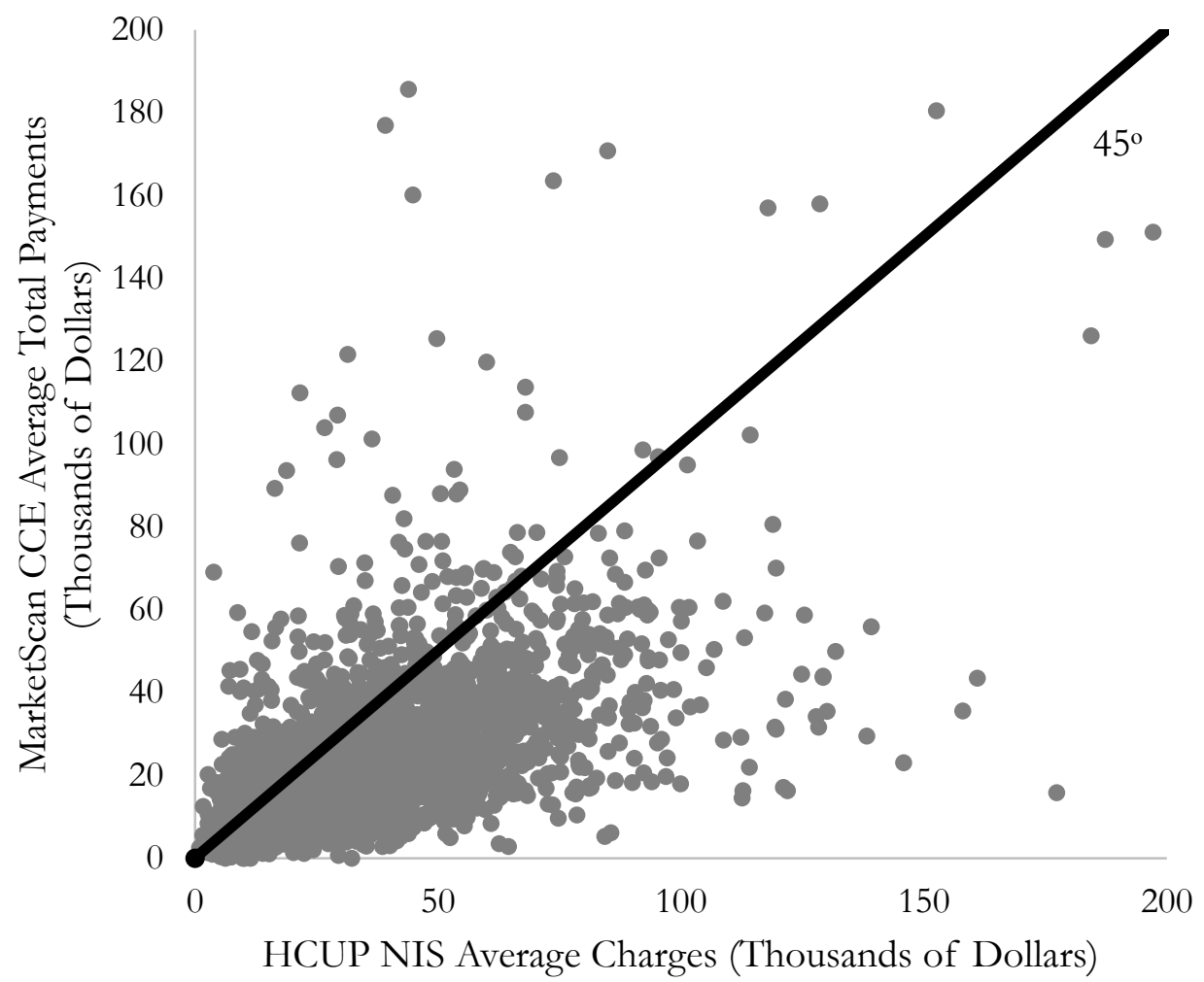

Notes: The figure compares MarketScan CCE Average Total Payments and HCUP NIS Average Total Charges for the years 2003 and 2004 for working age (20-64) men. MarketScan CCE Average Total Payments are constructed as the total claims (in thousands of dollars) for a state, year, DRG cell divided by the total number of patients in the cell. HCUP NIS Average Charges are constructed as the total charges for private patients only in a state, year, DRG cell divided by the total number of NIS private patients in that cell. The data points for the two samples are then merged by state, year, and DRG classification. The solid black line is a 45 degree line.

\title{
About the Authors
}

\author{
Kathryn L. Wagner : Department of Economics, Marquette University, \\ College of Business Administration, David Straz \\ Hall \#418, P.O. Box 1881, Milwaukee, WI \\ Phone: 414-288-3409 \\ E-mail: Kathryn.L.Wagner@marquette.edu
}

Journal of Health Economics, Vol. 49 (September 2016): pg. 46-58. DOI. This article is C) Elsevier and permission has been granted for this version to appear in e-Publications@Marquette. Elsevier does not grant permission for this article to be further copied/distributed or hosted elsewhere without the express permission from Elsevier. 